Journal of History Culture and Art Research (ISSN: 2147-0626)

Tarih Kültür ve Sanat Araştırmaları Dergisi

Vol. 10, No. 3, September 2021

\title{
DOI: 10.7596/taksad.v10i3.3080
}

Citation: Erarslan, A. (2021). Structural and Spatial Analysis of the Mosques of the Architect Sinan with Hexagonal and Octagonal Baldachin Systems. Journal of History Culture and Art Research, 10(3), 1-26. doi: http://dx.doi.org/10.7596/taksad.v10i3.3080

\section{Structural and Spatial Analysis of the Mosques of the Architect Sinan with Hexagonal and Octagonal Baldachin Systems}

Alev Erarslan ${ }^{1}$

\begin{abstract}
The master architect of the Ottoman era, Architect Sinan, created and left behind a wide range of structural typologies. The most numerous of Sinan's works were his mosques. The features defining the layout plan of Sinan's mosques are the central domed baldachin and the characteristics of the structure on which the baldachin rests. Sinan made use of multiple support systems of sometimes four, six or eight elements in his system of dome structures, planning the layouts of his mosques around the framework of these systems. Sinan handled each of his domed and multiple pillarsupported central baldachin in different ways in terms of both the foundation of the baldachin and of the side galleries, creating in this group of structures a "Sinan style." This paper is an attempt to make a comparative analysis of the organization of the domed central baldachin constituting the main space of the mosques of Architect Sinan, which is part of a hexagonal and octagonal baldachin system with multiple supports forming the central nucleus of the mosque, and of the side galleries, addressing the relationships between baldachin, structures, dome and galleries.
\end{abstract}

Keywords: Architect Sinan, Hexagonal Baldachin System, Octagonal Baldachin System, Structural Systems, Space Analysis.

\footnotetext{
${ }^{1}$ Assoc. Prof. Dr., İstanbul Aydın University, Faculty of Architecture and Design, Department of Architecture, Istanbul-TURKEY. ORCID: 0000-0003-2458-8788. E-mail: aleverarslan@gmail.com
} 


\section{Introduction}

The Ottomans' Master Architect Sinan produced a wide range of works in a variety of typologies that included mosques, hammams or bath-houses, madrasahs, masjids (prayer rooms), caravanserais, darüşşifa (hospitals), imarets, tabhane (guest houses), darülkurra (Koranic schools), and sıbyan mektebi (primary schools), leaving behind an expansive legacy. The most numerous of Sinan's works were his mosques. Sinan was responsible for the design of many mosques located in different regions of the Empire, particularly in Istanbul, and the space and plan organizations of his mosques were defined by the loadbearing structures the architect used in his domes. Sinan made use of multiple-support systems of sometimes four, six or eight elements in his dome structures, planning the layouts of his domed buildings around the framework of these systems. Architect Sinan treated each polygonal central baldachin differently, both in terms of its installation and also in reference to its adjacent spaces, thus virtually creating a new typology and style in this group of structures.

The principal structural component in Sinan's mosques was the dome. The most striking leitmotif he used in creating the construct of the central space and the notion of centrality was the dome and for him, this element was not only an element of mass in the spatial design but also a symbolic articulation. Sinan did not consider the dome as just a covering carried by the exterior walls of the building. The dome is the principal element used in determining the plans of his mosques, and this structure is an architectural component that dominates the entirety of the space and also the outer plastic of the building. Domes, which constitute a structural and symbolic covering, are thus the principal architectural components of Sinan's works. Sinan experimented with many designs in his mosques and his dome compositions, at the same time serving the purpose of shaping both the space and the mass (Kuban, 1988, p. 583). Dominating the interior space, the dome covering encompasses the fundamental principle of design that represents Sinan's style. The visual and physical relationship between the dome and the interior space completes the spatial impact. The dome was an important plan archetype and characteristic of Ottoman architectural style but also a stylistic form that crowned an architectural composition.

The domed central baldachin constitutes the nucleus of space in Sinan's mosques. The structural system of the baldachin is a construct of space that consists of different numbers and variations of load-bearing elements (pillars, columns, piers, massive wall piers, corner walls) that carry the dome, which acts as a covering over the space. The plan and the space have been developed around this baldachin. The dome and the central volume that is the baldachin dominates the structure from both the interior and the exterior, forming the backbone to the essential layout of Sinan's mosques. The system allows for a rich spatial construct, and a variety of spatial variations are thus made possible. The structural features the renowned architect of the Ottoman Empire Sinan used in his central domed baldachin motif determined the construct of the plan of the mosque. The domed central baldachin was usually mounted on loadbearing systems within the space. Using multiple support systems with four, six or eight elements, the master architect Sinan configured the layout of his domed buildings on the basis of these systems. By planting the main loadbearing pillars inside the space, Sinan was able to design different spatial plans in his central hall (Kuban, 1997, p. 74). The relationship between space, plan and loadbearing elements is different in each of his buildings. Each of his mosques was different in terms of structure and functionality and therefore Sinan treated the dome and consequently the spaces differently. The distribution inside the space of the loadbearing elements on which the dome rested, even in the same supporting systems, were formulated based on the concept of interior spaces carrying different features, where the relationships of the loadbearing columns with each other and with the covering and the organization of the side spaces varied. In this design, emphasis is given to structural principles (Cezar, 1977, p. 53). 
The construct points to a fundamentally tectonic approach and the structural design is the main determinant of the spatial arrangement.

This paper is an attempt to make a comparative analysis of the foundation and organization of the domed central baldachin constituting the main space of the mosques of Architect Sinan, which is part of a hexagonal or octagonal baldachin system with multiple supports forming the central nucleus of the mosque, and of the side galleries, addressing the relationships between baldachin, structures, dome and galleries.

\section{Sinan's Mosques with Hexagonal Baldachin Systems}

The typology of the hexagonal baldachin resting on a hexagonal substructure is one of the basic forms of Sinan's mosques. In structures of these types, Sinan devised the construct of the domed hexagonal baldachin and of the side spaces differently in each building he designed, thus producing different spatial constructs in each structure in terms of the main structure, the covering, the main space and the side spaces, depending upon how the loadbearing columns were set into the spatial arrangement.

The baldachin system Sinan used with the hexagonal base formed with the six loadbearing columns first appeared in the Sinan Pasha Mosque constructed in Beşiktas in 1554-1555-6 for Kaptan- I Derya Sinan Paşa. The mosque is situated in the kulliye standing in Beşiktas; it is a mosque in which Sinan offers a reinterpretation of the plan of the Edirne Üç Şerefeli Mosque. Making use of a structural system that resembles Üç Şerefeli Mosque, the architect has created a plan where a courtyard surrounds madrassah rooms in three directions and the horizontally expanding building's dome sits on a frame situated in front of a mihrab of $12.60 \mathrm{~m}$. in diameter (Figure 1). Four of the loadbearing elements on which the dome rests are similarly set into the walls in a north-south direction while the other two have been left freely in hexagonal formation in an east-west direction. The free-standing hexagonal columns are supported on the east and west sides by wall piers that spill out into the space. Sinan tied all of the columns making up the structural construct of the building to each other with pointed arches. The domed central space, as at the Üç Şerefeli, has been expanded to the sides (east-west) with double-domed side galleries. The building is Sinan's first experiment with a central space under a hexagonal canopy. Here, Sinan tapered down the dimensions of the large piers that had weakened the relationship between the side spaces and the central area at Üç Şerefeli Mosque, a decision that produced a more integrated central space (Kuban, 2007, pp. 78-79). The arches connecting the piers were also made higher. In dimensional and proportional terms, in this structure, smaller than Üç Şerefeli, Sinan reduced the dimensions of the loadbearing system in the space, thus forming a spatial construct that was well rationalized based on the structural experience gained from the classic period (Günay, 2002, pp. 31-32).

Seeking to add something new to each of his works, Sinan produced another interpretation of the domed hexagonal plan in the mosque built in Topkapı in 1558 for Kara Ahmet Pasha. Sinan shaped this kulliye's courtyard walls according to the street fabric and the geometry of the land. The mosque in the kulliye was built on slanted upland soil and is surrounded on three sides by madrassahs. The plan of the structure is a broad rectangle. The dome drum, of a diameter of $12 \mathrm{~m}$, rests on a hexagonal system of six spolia porphyry columns, two on either side of the mihrab wall, two next to the entry, and the other two with muqarnas capitals, standing independently in the middle (Günay, 2002, p. 32). Sinan has made a difference here by using a column instead of a pier and by leaving all of the six loadbearing elements freestanding in the space (Figure 1). Instead of hiding the loadbearing elements of the entry and those in the direction of the qiblah in the wall, he has placed them close to the wall. To support the main loadbearing pillars, he uses the west and east 
wall piers in back of the main loadbearers that project out into the space (Goodwin, 1971, p. 55). The connection of the east and west wall piers to the wall is achieved with connecting arches. The wall piers to the east and west are also supported on the outside with buttresses (Figure 1). These buttresses, which are a part of the structural system, are situated on the qiblah wall. The pillars that are independent of the walls and which constitute the hexagonal baldachin system covering the central space are tied together with semidomes with windows, thus embodying a wide and spacious interior. The connection of the wall piers on the east and west to the main walls making up the main body of the building is by means of pointed arches one level down from the windowed half-domes. Sinan places the two-story side galleries, which lie on two sides of the domed central space and serve as a congregational space for women, between the low arched areas tying the wall piers to each other on the east and west (Figure 1). The top of these side galleries, which are supported by two pillars on the lower floor, are covered with a cavetto vault that is independent of the dome.

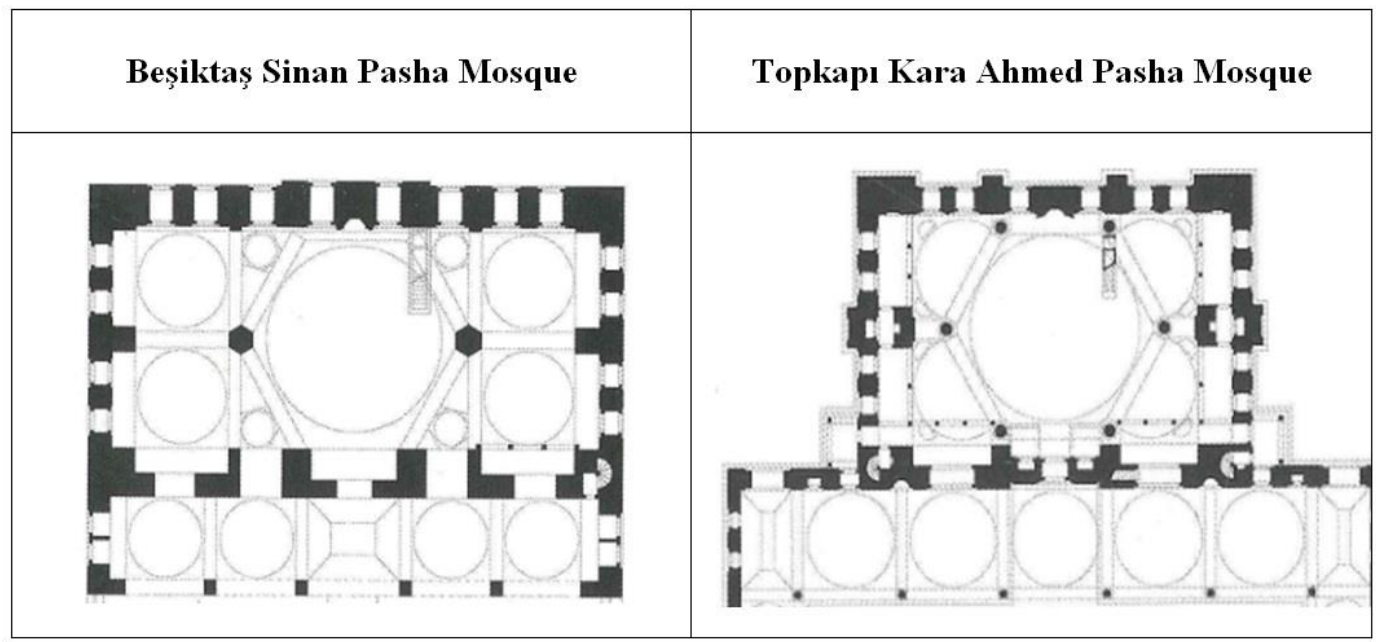

Fig 1: Beşiktaş Sinan Pasha and Topkapı Kara Ahmed Pasha Mosques (After Author).

Sinan's efforts to further develop his hexagonal structural bearings continued in new endeavors, one of which was the Babaeski Semiz Ali Pasha Mosque, a structure he designed 2 years after the Topkapı Kara Ahmet Pasha Mosque. This mosque was erected in 1560 and contains a kulliye that includes a madrasah, hammam, caravanserai and shops. The structure was built for Semiz Ali Pasha, who was brought to the position of Janissary Agha in 1546, becoming governor (beylerbeyi) of Rumeli and then of Egypt, The mosque was designed on a broad plan. Its mihrab projects outside in the shape of an iwan and it has a raised floor and a covering of a semi-dome (Günay, 2002, p. 78). In this case, Sinan presents a layout consisting of a congregational area with two rivaqs, a courtyard with no rivaq, and a broad harim (praying hall); the pillars on the south and north on which the $14 \mathrm{~m}$. diameter dome rests are joined to the wall in the form of a wall pier. The polygonal loadbearers on the east and west have been kept close to the body walls and tied to that wall with an arch (Figure 2). There are buttresses outside to support the pillars. Besides these buttresses, the building is also supported on the outside by two corner piers in the direction of the qiblah (Aslanapa, 1986, p. 111). The piers are connected to each other by windowed exedrae (or semidomes), elements that Sinan uses for spatial expansion. The harim is thus covered by the main dome that dominates the entire space. The two-storied side galleries (mahfil) of the building have again been designed as two-story structures between the polygonal wall piers on the east and west. The side spaces (mahfil) are connected to the domed central space on the lower floor with six pillars on each side. 


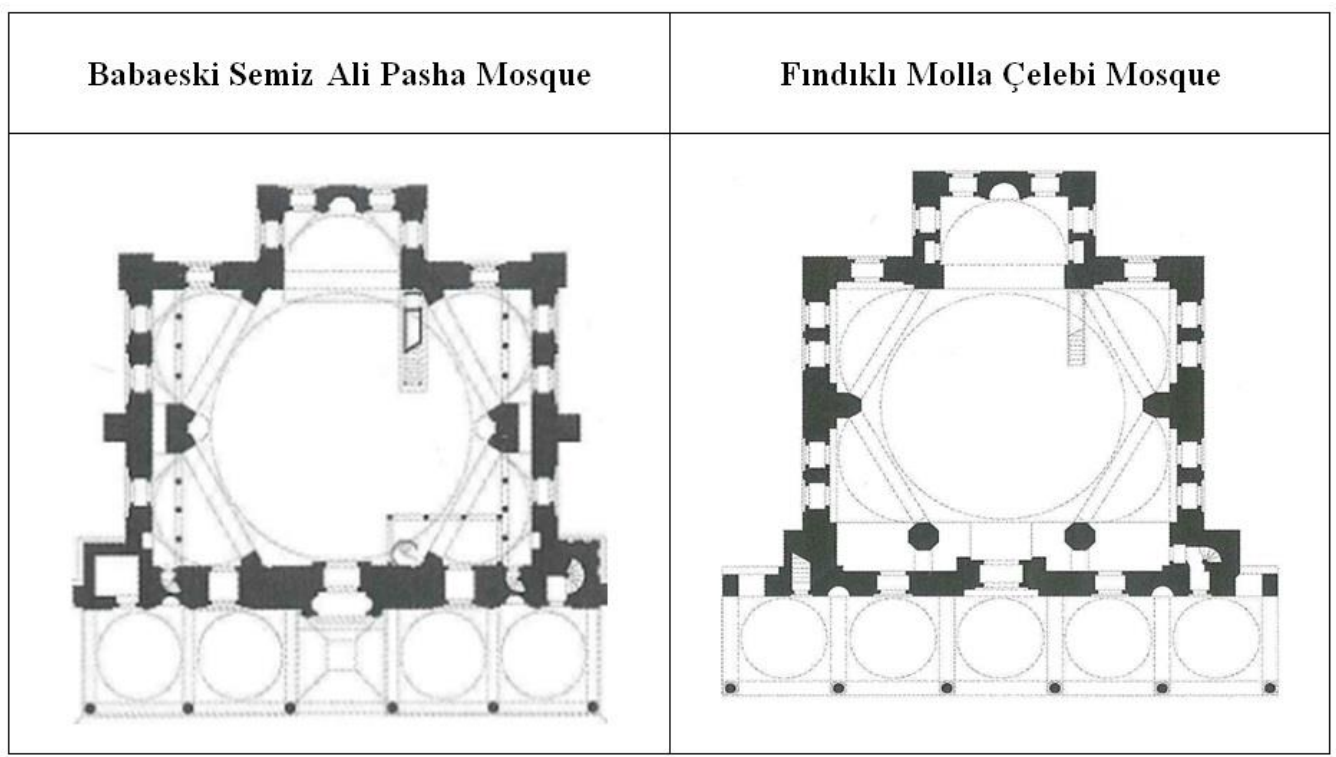

Fig 2: Babaeski Semiz Ali Pasha and Fındıklı Molla Çelebi Mosques (After Author).

The next phase of the Sinan's hexagonal structural experiments can be seen at Fındıklı Molla Çelebi Mosque. Molla Çelebi, or Çelebi Mehmed Vusuli, was a religious scholar known for his close relations with the palace in the era of Murad III (Kuban, 2007, p. 78). Believed to be built in the period 1561-1562, the mosque named after him has an almost square layout with a five-chamber congregational area in front. The courtyard was removed because of road construction. The mihrab is again in the shape of an iwan, projecting $6 \mathrm{~m}$. outwards and covered with a semi-dome. Sinan leaves the hexagonal baldachin freestanding on the entrance side (north) but implants 6 wall piers into the walls on the other sides (Figure 2). The pillars at the entrance side have an octagonal base and have been joined to the main wall of the structure with connecting arches. The embedded pillars are half-octagonal to the east and west. All of the pillars are this time connected with windowed squinches (Binan, 2016, pp. 242-246). The dome, of a diameter of $11.80 \mathrm{~m}$. sits on squinches on the inside and on a dodecagonal (12-sided) frame on the outside. Sinan does something different in this building, leaving aside the concept of the side gallery and designing only one on the north side in the name of creating an integrated and powerful central space. By doing this, the structure expands toward the north, taking on a rectangular shape that is almost square. In the east-west directions, instead of the side galleries, Sinan has simply designed two-story units with windows on a raised floor that sit inside the tromps tying the pillars together.

Another work of Sinan's that falls inside the group of hexagonally supported structures is Ivaz Efendi Mosque, located near Eğrikapı at Ayvansaray. Known popularly as Eğrikapı Mosque, the structure was built by Kazasker Ivaz Efendi shortly before his death. Dated to 1586, the mosque was built in the form of a kulliye. The structure lies on an almost square rectangular plan and is one of the group of buildings with an outward-projecting mihrab in the form of an iwan that is covered with a semi-dome. Measuring $15.60 \times 14.50 \mathrm{~m}$, the building is surrounded by a U-shaped congregational rewaq (Eyice, 1992, pp. 490-492). It resembles Babaeski Semiz Ali Pasha Mosque in terms of its loadbearing system and the placement of its pillars. The architect here has joined the columns that carry the $16.60 \mathrm{~m}$.-high dome, of a diameter of $9.80 \mathrm{~m}$., with the wall buttresses on either side of the entrance and on both sides (east-west), differing from Semiz Ali Pasha, has embedded them into the side body walls in the form of pilasters or wall piers (Figure 3). This way, all six of the pillars on which the dome rests have been embedded into the walls. All of the pillars are connected here again with windowed exedra with muqarnas, a plan archetype of which Sinan is particularly fond. This is 
something of an experiment for Sinan, who treats the concept of the hexagonal plan differently in each of his buildings. The two-story side galleries sit on six pillars below and wrap around the structure on three sides and are again situated in-between the wall piers.

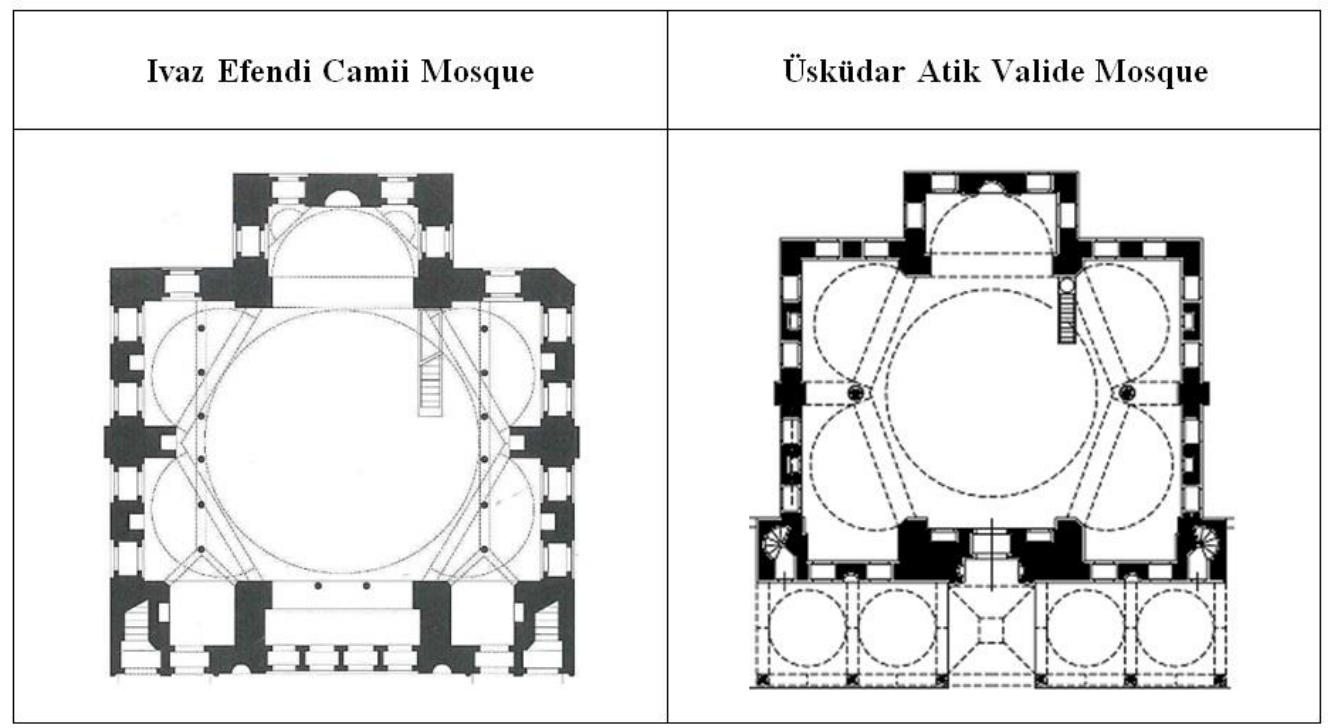

Fig 3: Ivaz Efendi and Üsküdar (Nurbanu) Atik Valide Mosques (After Author).

Another building in which Sinan uses the concept of a main dome resting on a hexagonal base inside a rectangular harim (praying hall) is Üsküdar Atik Valide Mosque. This structure was commissioned by Nurbanu Valide Sultan, mother of Murad III, and built in Üsküdar in the period 1570-1579. It consists of a very large kulliye, standing atop a hillside that towers over the Bosphorus at Toptaşı. On its east-west axis, the kulliye rests as a structure of organic design on a horizontally arranged asymmetrical plan, situated around its tiered terraces rising up against the hillside (Kuban, 1996, p. 34). The building attained its current appearance in three stages over history and it was Sinan who created the first version in 1570-1579. With its projecting mihrab in the shape of an iwan and covered with a semi-dome, the five-compartment congregational space contains a second revaq with wide eaves. The structure is in almost square rectangular form and the midsection is covered with a dome with a diameter of $13 \mathrm{~m}$. that is a dominating feature creating a massive appearance that prevails over the interior space. The dome of the hexagonal building rests on two wall piers in the south and east and on two pillars of brown-colored sumaki (prophyry) (Figure 3). All of the loadbearing elements are joined to each other with windowed exedra (Tanman, 1994, pp. 407-412). On the east-west axis of the structure, there are piers built as additional structural elements that project both toward the inside and the outside. The wall piers and pillars are connected by joining arches. As in Karaahmet Pasha Mosque, Sinan has connected the building's body walls on the eastwest axis with wall piers, using exedra that tie the main pillars and have pointed arches on the level below. The side galleries in the east, west and north of the building are situated in a two-story composition in-between the wall piers.

Sinan applied different structural programs of the hexagonal baldachin. One of these is Sokullu Mehmet Pasha Mosque, built in Kadırga in the era of Süleyman for one of the most influential grand viziers of the times. Sinan's experiments with hexagonal canopies displayed its most mature version in the structure situated close to the palaces built by Sokullu in Kadırga. The building, which was constructed in 1571 on the ruins of the famous Byzantine Grand Palace, is situated on an uneven hillside running from east to west, on land that was in the center of the old city (Kuban, 2007, pp. 45-46). The mosque, madrassah and lodge make up the kulliye. Sinan made use of the terracing 
method that he found the most effective way of dealing with problematic land in terms of the spatial organization of the city. This method enabled him to rest the different parts of the kulliye on different levels. The structure is accessed from stairs that are situated beneath the low-level madrassah classroom and have a view of the mosque, the courtyard rewaq, and the fountain (Kuban, 1994, pp. 32-34). The building is a testament to Sinan's mastery of creating an association between the structure and the land and so, in terms of the hexagonal-dome design, there is a perfect sense of integration visible.

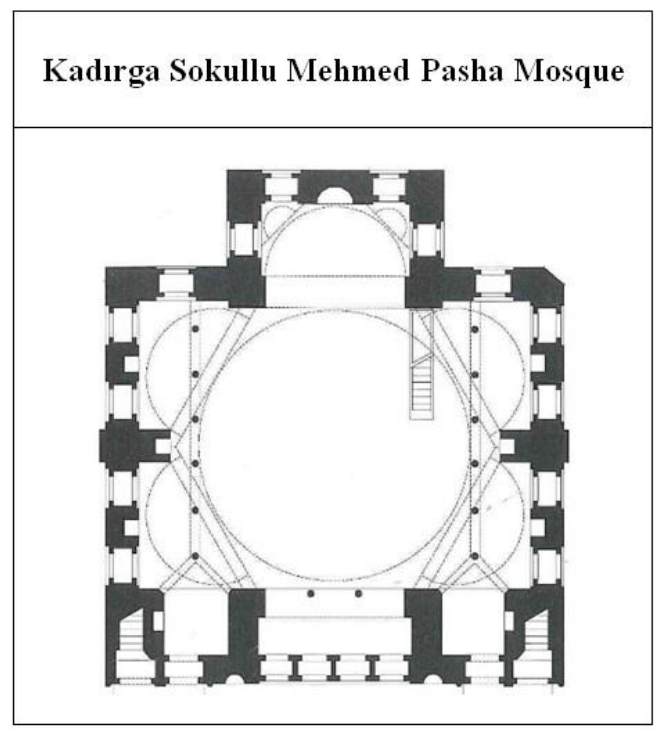

Fig 4: Kadırga Sokullu Mehmed Pasha Mosques (After Author).

The harim (prayer hall) that is of the dimensions of $15.30 \times 18.80 \mathrm{~m}$ and that stands on a rectangular plan expanding on a horizontal plane is completely integrated with the space with its hexagonal pillar system (Kuban, 2007, p. 66). In Sinan's design, the hexagonal sub-structure of the building is joined to the walls on all sides with six columns in the form of piers (Figure 4). The pillars on the side walls are polygonal but rectangular at the qibla and entrance. The dome, $13 \mathrm{~m}$. in diameter and $22.80 \mathrm{~m}$. high, rests on two side pillars in an east-west direction that project outward, serving the function of a buttress (Binan, 2016, p. 324). The loadbearing pillars have been joined with windowed semi-domes with muqarnas decorations inside. Underneath the dome, in the middle area, the space expands, again by means of the two-storied, narrow, low-ceilinged, raised galleries that have been placed again in-between the wall piers (Necipoğlu, 2005, pp. 13-14). The upper floors of the side galleries do not have a tiered covering and have therefore been kept high, forming a homogeneous effect with the main space. The proportions of all of the elements of the structure and its units strengthen the harmony and unity of the space, presenting a balanced and strong spatial effect in the central space.

\section{Sinan's Mosques with Octagonal Baldachin Systems}

Another structural group that gave way to new typologies in Sinan Agha's attempts to create a central space was the group of mosques with octagonal baldachin systems. In this group of structures, Sinan rests the domed central space and baldachin on octagonal loadbearing elements. The side spaces are again conceptualized around this domed central space and baldachin situated on an octagonal base. 
Sinan used the octagonal canopy or baldachin system first in Silivrikap in the structure known as Hadim Ibrahim Pasha Mosque built for Hadim Ibrahim Pasha, one of Suleyman the Magnificent's grand viziers. The mosque, dating back to 1551 , is part of a kulliye program that includes a hammam, open tomb (türbe) and a sibyan mektebi (primary school). The structure, set upon a square plan, is covered by a single dome with a diameter of $12 \mathrm{~m}$ and has a five-compartment congregational area (Kuran, 1986, pp. 98-99). Sinan has embedded the octagonal baldachin on which the dome rests in the walls from all directions, supporting it with wall piers that project toward the inner space (Figure 5). The wall of the qiblah (mihrab) wall has been designed to be thicker than the other walls and therefore the wall piers on this side project less into the inner space (Sönmezer, 2003, pp. 88-89). The transition elements leading to the dome are oyster shell-shaped grooved squinches that are supported with consoles with muqarnas vaulting.

Sinan has placed the side galleries in the form of niches in three directions (east, west and north) that rest in-between deep wall piers that project out into the space. The niche-like side galleries broaden the main area; they are built on a single story and have three divisions, with the one in the middle being wider and higher. Besides providing spaciousness, the side galleries also reduce the pressure exerted by the dome (Eyice, 2000, pp. 341-343). The wall piers that act as the main loadbearing structure in the building are joined together by pointed arches made of twocolored stone. The galleries set in-between the wall piers thus end in pointed arches on each side (Necipoğlu-Kafadar, 1986, p. 224). The single-story side galleries have been designed as a narrow space to permit only a single person to kneel and pray; the area is raised higher than the harim (praying hall). In this arrangement, the prayer areas inside the niches, or side galleries, are segmented due to the wall piers and therefore the resulting effect is a lack of integration as a side gallery. The walls of the single-storied niches with their pointed arches have two rows of windows to allow light into the space.

Seeking a new mode of expression in each of his works, Sinan produced another interpretation of the octagonal scheme in Tahtakale Rüstem Pasha Mosque, which was built for Rüstem Pasha, husband of Mihrimah Sultan and a great patron of many buildings and kulliyes that were built in numerous parts of the Empire. The structure was built in 1555-1561 and is located in a highly commercial part of the city. When it was built, the building, with its dome of a diameter of $15.50 \mathrm{~m}$, was the most dominant silhouette along the shoreline (Kuban, 1997, p. 77). By making meticulous use of his professional skills in dealing with topographical conditions in this very valuable area of the city, Sinan succeeded in organically situating his mosque, designing it with two khans (caravansarai) and stores on a lower level, raising the floor of the mosque using a vaulted platform to be one floor over the shops below, thus placing the shops along the road level beneath the mosque (Turani, 1997, pp. 44-45). It was in this way that the new addition to the city would benefit from the commercial potential of the area and also increase the visibility of the structure (Necipoğlu, 2013, pp. 14-16). By elevating the structure, Sinan was able to give the building a magnificent view of the sea, enhancing the city vista. The contours of the outer plan of this broad and spread-out structure measure approximately $38.00 \times 38.00 \mathrm{~m}$. Its dome, with a diameter of $15.20 \mathrm{~m}$ and a height of 22.80 $\mathrm{m}$. hovering over the front of the mihrab, rests on eight supports-four free-standing octagonal piers and another four wall piers in the direction of the mihrab and entrance (north) (Figure 5). The pillars and wall piers project somewhat toward the east, west and south directions and are supported by secondary wall piers acting as buttresses. The structural genius Sinan joined the main loadbearing elements with these secondary loadbearers with connecting arches. Connected with alternating 
exedra and arches, the main loadbearing masses create an octagonal central space in the middle of the harim. The free-standing four pillars are also designed on an octagonal plan, accentuating the concept of the baldachin (Kuban, 1997, p. 78).

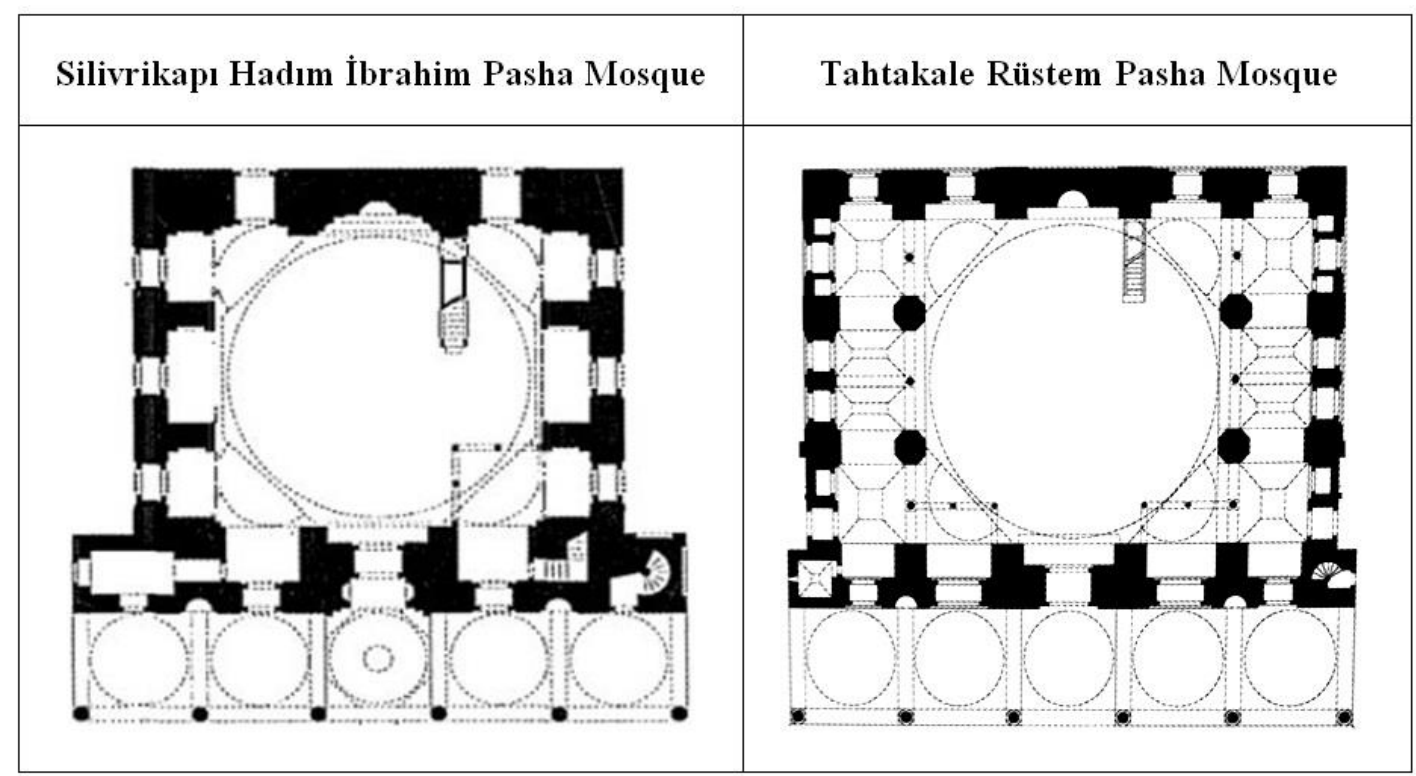

Fig 5: Silivri Hadım İbrahim Pasha and Tahtakale Rüstem Pasha Mosques (After Author).

In the back of the free-standing pillars in the central domed space, in an east-west direction are three-compartment, two-story, low, narrow galleries that have been situated in-between the secondary supporting wall piers. The galleries look toward the main entrance and sit between the piers. The side galleries open out into the interior space (harim) on both stories, creating a homogeneous effect with the domed central space. The side galleries rise up to the hoop of the dome and are covered by cavetto vaults on the inside, appearing to be covering only the central opening from the outside while the other spaces are covered by the dome (Necipoğlu, 2005, pp. 99100). Uğur Tanyeli has called the domes placed on top of the covering on the outside "fake domes" and suggests that this was done to give the structure a more formidable outward appearance (Tanyeli, 1990, pp. 68-71). The building has a five-compartment congregational area with two rewaqs. This arrangement constitutes the first stage of Sinan's experiments with octagonally-based central spaces that he created with independent vertical loadbearing elements (Batur, 1969, p. 140).

Another structure in which Sinan used octagonal loadbearing elements is Nişancı Mehmed Pasha Mosque in Fatih. Built in 1584-1589, this is a kulliye that includes a mosque, madrassah and Islamic monastary. Some sources say that the edifice was completed after Sinan's death by the architect Davud Aga (Kuran, 1986, p. 55). It is accepted as being his last work and is characterized by a zig-zag contour running toward the qiblah, a technique that Sinan adopted to rescue it from being a boring classic composition affecting the appearance of the outer mass (Figure 6). The structure is covered with a semi-dome and its mihrab, projecting outwards in the form of an iwan, enhances the effect. Thus, the structure departs from the strictly rectangular geometry in its massive lines, and its central, domed octagonal baldachin, fixed into the corners of the building's body walls, is supported by eight polygonal piers connected to the walls (Fig 6). The four piers to the north have been separated from the wall on the second-floor galleries, standing independently (Necipoğlu, 1996, p. 183). These free-standing piers are joined together with connecting arches. The eight loadbearing elements are connected with windowed tromps with muqarnas consoles at the corners and again also with windowed semi-domes. The central space in-between the pillars is covered by a dome with a diameter of $14.20 \mathrm{~m}$. 
The side galleries have been placed between the pillars to the east, west and north. The galleries surround the main area on three sides and are made of two units on the east-west side and they are two-storied and larger. This central space, covered with a windowed semi-dome, has been kept very high on the upper floor, emphasizing the impact of the octagonal baldachin (Figure 6). The spacious and high-ceilinged upper floor of the middle volume has bannisters and the lower floor is joined to the main area with two pointed arches on either side. The second units of the side galleries along the east-west are covered with cavetto vaults (on the north); they are again two-storied and are joined to the tabhane (guest rooms) at the north corner of the mosque on the lower floor, and function as a connecting room The sole connection of these units with the interior space is the windows opening out into that space (Sönmezer, 2003, pp. 88-89). The independently standing wall piers, broken off from the walls, rise toward the upper floors and between them lies the harim (prayer hall), accessed through an arch that is at a lower level than the middle gallery. The way the corner side galleries open out into the interior space with a low arch on the upper floor and the manner in which the middle gallery unit has been raised to a higher level increases the structural effect of the vertical loadbearing elements. The galleries on the north side are again arranged in the same way. They appear to be looking down upon the interior space from in-between the freestanding piers that have been pulled away from the wall.

There are eight towers on the external mass of the building, rising from the polygonal piers that constitute the main loadbearing system of the structure. These towers echo on the outside the emphasis on the sense of escalation felt in the interior of the building (Kuban, 1994, pp. 85-87). The side galleries and the main wall have a three-story window arrangement on their facades. The combination of the semi-dome covering the main galleries, the windows of the exedrae and the hoop of the dome raises the number of window arrangements to four, creating both a sense of elevation and providing a source of intensive light. There are more tabhane rooms, covered with cavetto vaulting, at the northwest and northeast corners of the mosque. The entrances to the mosque are in the congregational space and their relationship to the actual prayer area has been achieved with a network of wrought iron windows.

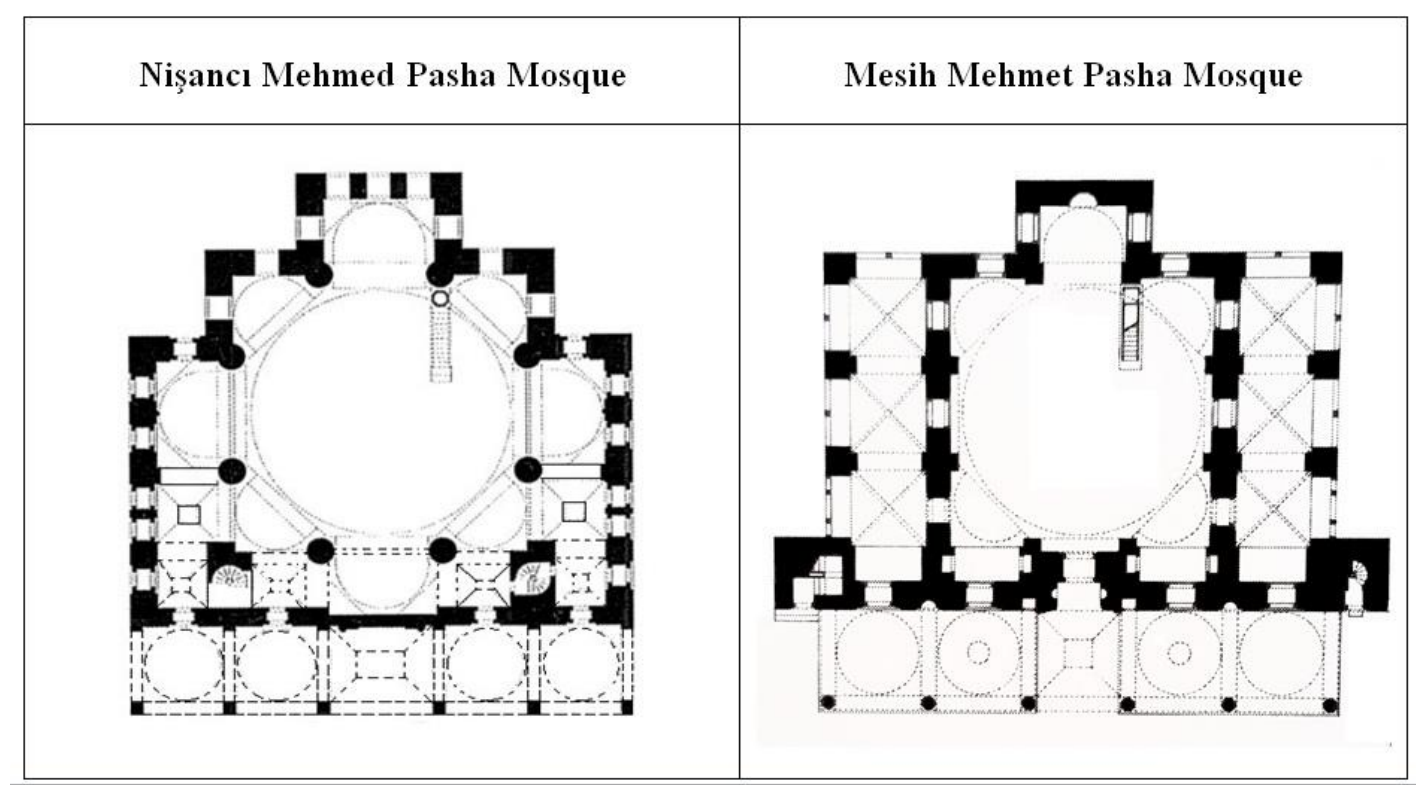

Fig 6: Nişancı Mehmed Pasha and Mesih Mehmet Pasha Mosques (After Author).

Another structure where Sinan makes use of an octagonal base is in Çarşamba, in Mesih Mehmet Pasha Mosque, which was built in 1585-1586 by Hadim Mesih Mehmed Pasha, one of the Grand Viziers of Murad III. Although the building's registration in Tezkiret ül-Ebniye and Tuhfet ül- 
Mi'marin indicate that this structure is a work of Sinan, it is thought that the architect Davud Agha, an apprentice to the Grand Master adhering to the principles of his school of design, contributed to its design (Sönmezer, 2003, p. 89). Situated at an intersection of two streets on an incline, the building's foundation has been raised by means of shops to create an even plane.

The mosque has twin congregational spaces, and its horizontally rectangular plan with its single-domed harim (praying hall) serves as an important example of the octagonal support system. With its semi-domed mihrab projecting outwards, the octagonal canopy has been set upon wall piers that have been arranged on a plan of two in each direction (Figure 6). The wall piers have been tied together with windowed squinches at the corners and are joined with arches. The octagonally supported structure is crowned by a dome with a diameter of $12.80 \mathrm{~m}$. that has windows on its hoop. On the outside of the eight wall piers that constitute the loadbearing system rise weight towers of polygonal form.

The harim is surrounded by two-storied, three-compartment side galleries placed in between wall piers in the east, west and north. The wall piers on the east, west and north (where the main entrance stands) have been joined to the wall on the ground floor, but as from the gallery (mahfil) floor, they rise freestanding (Sönmezer, 2003, p. 90). The lower floors of the side galleries or mahfil are covered with vaulting and only the mahfil opening out to the main space to the north has an interior door. Another element tying the lower stories to the main space is the windows looking out into that area. The lower stories of the side galleries have separate entrances from the outside on the east and west facades. It is thus in a sense possible to enter the lower floors, which take on the identity of a closed outer rewaq that does not project out from the mass of the building, both from the inside and the outside. The lower stories of the side galleries have been abstracted from the interior space (Erzincan, 2004, p. 311).

The upper floors of the galleries however open out into the harim with three pointed arches each in three separate units rising independently from the piers as from the gallery floor. The embedded wall piers on the lower floor rise to the level of the mahfil (upper floor), making it possible to more easily view the octagonal base of the structure (YIImaz, 2015, p. 67). The galleries are joined to the piers on the upper floor, which have been broken off from the wall to rise independently, by connecting arches. The upper floors are covered by a pendentive dome and open toward the inside in the form of wide galleries, making it possible for the loadbearing system to become independent on the upper floor (Okçuoğlu, 1994, pp. 406-407; Erzincan, 2004, pp. 310-312). This way, the galleries opening to the outside on the lower floor have been converted into interior galleries opening out into the interior of the mosque on the upper floor. The piers appearing on the upper floor are joined to the body walls with connecting arches. Here, the Architect Sinan not only expands the space on the upper floor but, by preventing the middle area from spreading out toward the sides on the ground level, creates a differently constructed interior space (Erzincan, 2004, pp. 310-312).

Another structure where Sinan designs an octagonal canopy is one that he called his "Master Work"-Selimiye Mosque. This mosque was taken into the scope of UNESCO's World Heritage List in 2011. It is situated in Edirne at the site of the old palace in the center of the city on a square that is called Kavak Meydanı. Built by Sultan Selim II, the structure comprises a kulliye, which includes, besides a mosque, a madrassah on both the southeast and southwest, a bazaar area (arasta) and a primary school on the west (Mülayim, Çobanoğlu, 2009, pp. 430-434). Looking over the Edirne landscape on flatland that is not very wide, the kulliye, which was built to the west of the city center defined by the Old Mosque and the marketplace in 1568-1575, carries the parameters that Sinan placed importance on in his city planning, forming an excellent connection between the topography and the surroundings. Rising up at the apex of the Ottoman center of trade and providing a view of the city from all sides, the mosque, with its access to the city units surrounding it, benefits from a 
darülhadis and darülkurra facing the qiblah and from an arasta, or bazaar, on the southwest (Ahunbay, 1988, p. 134).

The mosque has been designed with a mihrab that projects outwards and in the spatial arrangement of the kulliye, Sinan has planted within the octagonal plan inside the square, eight piers with dodecagonal bodies, six of which stand independently in the area and two of which are situated to the south inside the corners of the mihrab niches. As a support for the octagonal pier that forms the central baldachin, on the sides of the two piers on the north, Sinan has added two more piers of square form to act as secondary loadbearers (Figure 7). Connections between all piers have been achieved with an arrangement of alternating exedra and arches. The main piers, starting from the gallery floor, have been joined to the body walls by means of connecting arches. The piers above the mahfil or gallery floor are joined together with broad suspended arches. In this way, the main loadbearing piers inside the space that are joined with an arrangement of windowed arches and exedra and the suspended arches above the lower level gallery create a graduated profile.

By situating the piers along the edges of the wall, the large space in the middle has been kept within the boundaries of the central dome and thus the central plan remains expansive and roomy and achieves spatial integration. Above the main space, which stands on an octagonal base, is a dome, $42.25 \mathrm{~m}$. high and with a diameter of $31.30 \mathrm{~m}$. (Mülayim, Çobanoğlu, 2009, p. 433). Because of the increase in the number of piers in the structure, gaps are closed and the dome appears to be even higher and more dominant over the building (Günay, 2002, pp. 34-35). The concept of design in the mosque boasts of a commanding and predominant dome and central space. Doğan Kuban asserts that the choice of an octagonal design allows Sinan to create a commanding space that suggests absolute sovereignty (Kuban, 2007, pp. 167-168).

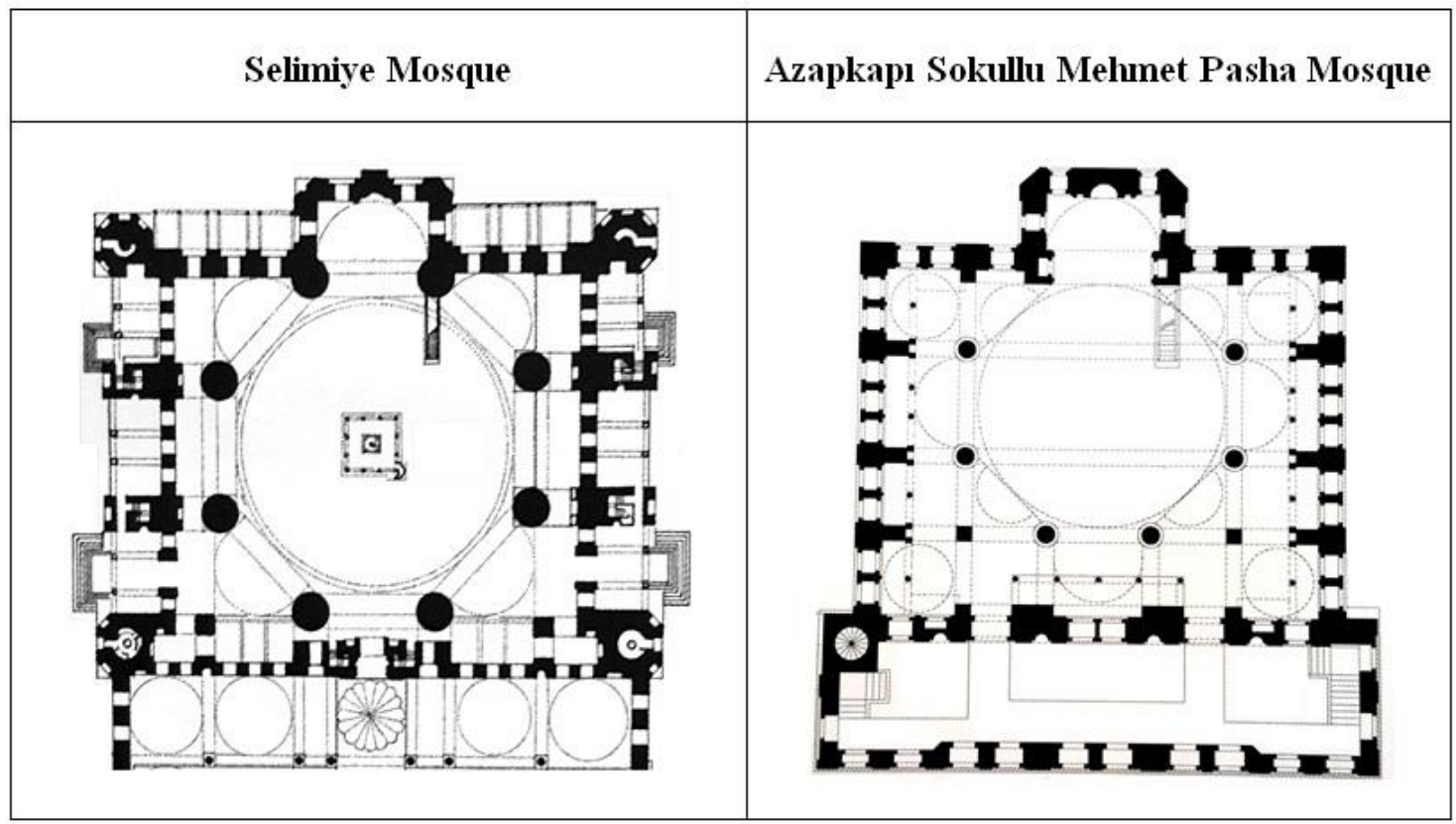

Fig 7: Edirne Selimiye and Azapkapı Sokullu Mehmet Pasha Mosques (After Author).

In this structure, which emphasizes the dominance of the dome over the space below, the weight and stress of the $31 \mathrm{~m}$. diameter dome is supported in Sinan's design with a buttress system that surrounds the octagonal central overhead covering. The eight piers on which the dome rests are supported on the outside with buttresses. The main pillars and buttresses are connected to each other with arches. Thus, the weight of the dome is carried by the main columns and the buttresses 
connected with connecting arches (Günay, 2006, p. 213). Since the loadbearing system is independent from the wall, an ambulatory system has been formed behind the columns. There is a corridor that is situated between the side galleries and the main structural columns. The main structural columns on the east, west and north have been joined to the wall with connecting arches, starting from the mahfil story. The top of the ambulatory has been covered with thick suspended arches. The floor of the passageway has been raised to a level that is higher than the main area.

Outer galleries (riwaqs) of different sizes wrap around the structure from the outside on the east, west and south (Figure 7). These exterior side galleries, called "zulla," represent the culmination of Sinan's exploration of mass expression that he exhibited in his Şehzade, Süleymaniye and Selimiye mosques (Tanyeli, 1990, p. 68). The external mahfils (galleries, riwaqs, zulla) differ from the Süleymaniye and Şehzade mosques in that here, they also appear outside the south (qiblah) wall. With his side rewaq system, Sinan has created a transition between the exterior and interior space. These side galleries that open into the outer space form a connection between the harim and the outside.

On the interior, the structure is surrounded by side galleries (mahfil) that surround the harim from three sides in U-formation. On the north side, the mahfil have been situated between the square-based secondary pillars that have been added to the sides of the polygonal pillars (Kuban, 2011, pp. 64-65). On the east-west side, the galleries have been placed between the buttress pillars that reinforce the main columns. The three-unit (the middle one being more spacious) east-west side galleries, two-storied and on a higher level than the main area (harim), have windows looking into the interior space on the lower floors. Only the door of the north mahfil opens out into the main hall. This arrangement is what Sinan used in Mesih Mehmet Pasha Mosque and somewhat in NişancI Mehmed Pasha Mosque. In front of the upper stories of the side galleries with their three arches looking over the harim is a railing with a Bursa type of arch. Both stories of the galleries in the north open out into the main space. Sinan has thus applied a different organization to each of the side gallery wings, creating a dynamic and animated effect. Sinan situated the muezzin mahfil in the center of the structure for acoustic reasons, placing it right underneath the dome (Figure 16). In this case, sebu cubes (cubes used in acoustics) have not been used and beneath the muezzin mahfil, stands an inner fountain that provides a welcome coolness to the space and accentuates the centralized effect of the interior (Benian, 2011, p. 43).

The exterior silhouette of this structure, with its central dome supported on eight sides, is a reflection of its interior arrangement. The integrated graduation seen in the inside can be viewed in the outer plastic of the building as well. Sinan creates a graduated effect by resting the counterweight towers sitting on the eight pillars on the drum of the dome, keeping the buttresses on the lower level (Kuban, 1997, p. 92). All of the walls of the building do not serve a loadbearing purpose and the insides of the wall surface have been equipped with windowed and pointed arches that create a graduated effect on the facade. The three minaret balconies, $71 \mathrm{~m}$. high, contribute to the pyramidal appearance of the building with their elevation. The relationship between the mass of the mosque and its minarets is in complete and integrated harmony with the dome (Aslanapa 1986, pp. 89-90). The octagonally supported plan finds expression on both the inside and the outside silhouette.

The last structure in which Architect Sinan Aga used the octagonal-based baldachin was Azapkapı Sokullu Mehmet Pasha Mosque, which he designed after Selimiye. Built in 1577-1578 by the Grand Vizier Sokullu Mehmed Pasha, the mosque lies at the Şişhane foot of the Unkapı Bridge. Azapkapı Mosque was named for the city gate that is situated here (Eyice, 1994, pp. 30-31). The mosque rises on a vaulted substructure that rests on a pile foundation. In front of the building, on a raised platform, is a closed congregational space that is covered with a roof slanted toward the front. The minaret is independent of the structure and stands to the north of the congregational hall.

With two chamfered corners, windows on its sidewalls, its mihrab projecting outward and covered with a semi-dome, this building was designed by Sinan as an application of the octagonal canopy system for its central plan. In the harim, set on a square plan, the central dome sits on eight 
piers on the east, west and north, two on each side and standing independently, and on the south on two polygonal ones that are joined to the mihrab niche at two corners. The upper half of the piers are grooved (Figure 7). As in Edirne's Selimiye, Sinan has added here as well two square-based piers that he has planted next to the two piers in the north as secondary loadbearers to support the eight polygonal piers that make up the central baldachin (Sönmezer, 2003, p. 92). There is again a weight tower on each of the piers on the exterior. The piers have been joined together in alternating series of windows, tromps and semi-domes. In this way, the central dome, $11.80 \mathrm{~m}$. in diameter, is supported by four tromps and by semi-domes on the east, west and north sides.

Another part of the loadbearing system of the structure is the wall piers that have been embedded in the wall in all directions while also projecting out into the central space, acting as supports for the independent piers making up the octagonal baldachin. These thick piers act as buttresses and actually support the main piers that carry the central dome. The wall piers are joined to the main piers on all sides by connecting arches (Kuran, 1976-77, pp. 83-90). Sinan has repeated his prowess with the composition of the side galleries and has situated these on two stories inbetween the wall piers jutting towards the interior on the east, west and north sides. The four-unit side galleries on the lower floor are carried by columns; the unit in the middle is broader and the ones in the corners are covered by the dome (Kuban, 1994, pp. 32-34). The harim has bannisters with basket arches on three sides, and the side galleries are at a higher level than the central space. The structure exhibits an ambulatory that wraps around the octagonal baldachin beneath the central dome and behind this, two-storied side galleries (mahfil) that surround the structure on three sides in the shape of a $U$. The entire space is covered by a single dome and the broadside galleries are visually integrated with the main area. This structure was built after Edirne's Selimiye Mosque and is its small-scale model. Doğan Kuban asserts that the building carries the weight of Sinan's Selimiye experience (Kuban, 2007, pp. 62-64).

\section{A Comparative Analysis of the Relationships Between Supporting Systems, Dome, Main Space and Side Gallery}

The main schematic and spatial archetypes Great Sinan used in his hexagonal and octagonal baldachin system mosques were the loadbearing system making up the main structure, the main loadbearing structural elements where the domed central baldachin rested (pillars, columns, piers, massive piers, wall piers), the buttresses that lessened the weight on the main loadbearing elements, the arches, exedra and semi-domes that made up the dome-supporting systems, and the tromps (squinches), similar curvilinear elements that provided the transition from the main dome, and the side galleries (mahfil).

With his hexagonal baldachin creating a homogeneous central space in his mosques, the Ottoman master architect Sinan set up this hexagonal element in four different ways. The first of these can be seen in the Topkapı Kara Ahmet Pasha Mosque, where all of the loadbearing elements have been situated in the form of pillars, set out independently within the main space in the direction of the qiblah and in the north and east-west directions. The second hexagonal structural system consists of a wall pier with four posts embedded in the wall on the qiblah and entrance side (north) and another two (east-west) standing independently within the central space. The structure in which Sinan tried the hexagonal canopy for the first time was Beşiktaş Sinan Pasha Mosque. The same structural construct was used in Atik Valide Mosque, where the east-best loadbearing elements were in the form of columns. In the third concept, the vertical loadbearing elements are this time resting on six pillars on all sides in the form of a wall pier that connects all the walls. This scheme is also used in the Ivaz Efendi and Kadırga Sokullu Mosques, where the pillars are pilasters buried in the walls. Babaeski Sadrazam Semiz Ali Pasha Mosque is in this group. Here, the pillars on which the dome rests on the south and north sides have been joined with the wall in the form of a wall pier, and the loadbearers in the east and west have been kept close to the wall and affixed to it with connecting arches, lending a different approach to the concept. The fourth arrangement that Sinan employed to provide a hexagonal canopy for the dome to rest on can be seen at Fındıklı Molla Çelebi Mosque. Sinan leaves the hexagonal baldachin free on the entrance side (north) but implants 6 wall piers into the 
walls on the other sides using six pillars. All of the main structural columns in this group are joined together with building elements such as semi-domes, exedra or squinches with windows or arches that broaden the space and make it more spacious. The main columns and the central hexagonal baldachin composed of a system of arches, a semi-dome and squinches are covered with a pendentive dome.

As a supporting element to the main structure in this group of mosques, Sinan reinforces the main loadbearing pillars and the wall piers that the central hexagonal baldachin rests on with buttresses that act as structural additions. The first additional buttress system carrying the weight and stress of the dome was used in the Beşiktaş Sinan Pasha Mosque. Here, Sinan supports the freestanding hexagonal columns on the east and west sides with wall piers that spill into the space. At Topkapı Karaahmet Pasha Mosque, wall piers are used to support the free-standing main loadbearing pillars on the east, west and north sides (Figure 1). The wall piers on the east and west sides are joined to the wall with connecting arches. The wall piers to the east and west are also supported on the outside with buttresses. These buttresses, which are a part of the overall structural system, are situated on the qiblah wall. Another example of Sinan's technology of using wall buttresses to provide additional support to the main structure of the building can be seen at Babaeski Semiz Ali Pasha Mosque. Here, Sinan has placed the loadbearing pillars comprising the hexagonal construct on the east and west sides close to the body walls of the building, connecting them with arches, while situating wall buttresses to support the pillars from the outside (Figure 2). At Üsküdar Atik Valide Mosque too, the independent pillars standing on the east and west sides that make up the hexagonal baldachin with its central dome are supported with the additional structural elements of wall piers on both the inside and outside of the building. The last building in this group is the Kadırga Sokullu Mehmet Pasha Mosque. Here, two of the side pillars of the hexagonal substructure comprised of wall piers that join the walls on all sides spill out to serve the function of a buttress (Figure 4).

Sinan often expanded the hexagonal baldachin of his mosques of these types toward the east, west and sometimes to the north with side areas galleries (mahfil or galleries, sahın or naves). These side spaces that Sinan used to expand the area are organically integrated with the domed central space. The side spaces are also used to soften the effect of the overpowering structural composition of the dome. Sinan uses four basic constructs in these side galleries to surround the central space covered by the dome and soften the relationship between the load-bearing wall and the covering in the tradition of domed structures. An example of this is Beşiktaş Sinan Pasha Mosque, where Sinan's first side space organization features an expansion of the hexagonal domed central space into double-domed side galleries. The building in this way can be categorized in the group of horizontally expanding mosques with areas on the side (Figure 1). This is an example of the type of baldachin that rests on six pillars and expands toward the sides and the domed side units supporting the domed central space are in full integration with the interior central area.

In the spatial organization of having secondary side areas as in this group of buildings by Sinan, the side areas (galleries) lie in an east-west direction from the hexagonal canopy over the central space. Situated between the wall piers on this side, the praying area (harim) is on a higher level and is composed of two stories. In this arrangement, used in the Babaeski Ali Pasha, İvaz Efendi and Kadırga Sokullu Mehmed Pasha mosques, the side galleries on the lower floor open out with pillars that are connected with arches (Figures 8, 9). Here, Sinan has created a different system of covering for these spaces, which are independent of the dome and covered with vaulting or a flat roof, providing the atmosphere of the structure with mobility.

In his third treatment of galleries in the structural construct of the hexagonal baldachin, Sinan places these side areas in back of the main loadbearing elements that support the hexagonal canopy, supporting these by placing them between wall piers that jut out into the space on the east, west and north sides. These piers that are a part of the structural system are tied to the main building body in the north-south direction with windowed half-domes that keep the main pillars together, one of which is covered with pointed arches on the lower level. Sinan's Topkapı Kara Ahmed Pasha and Üsküdar Atik Valide Mosques are practical examples of this application and on the 
lower floor, they display raised galleries that open out into the main space with two pillars. The upper floors have a balustrade in front and open out into the domed hexagon-based central space with low pointed arches (Figure 10).

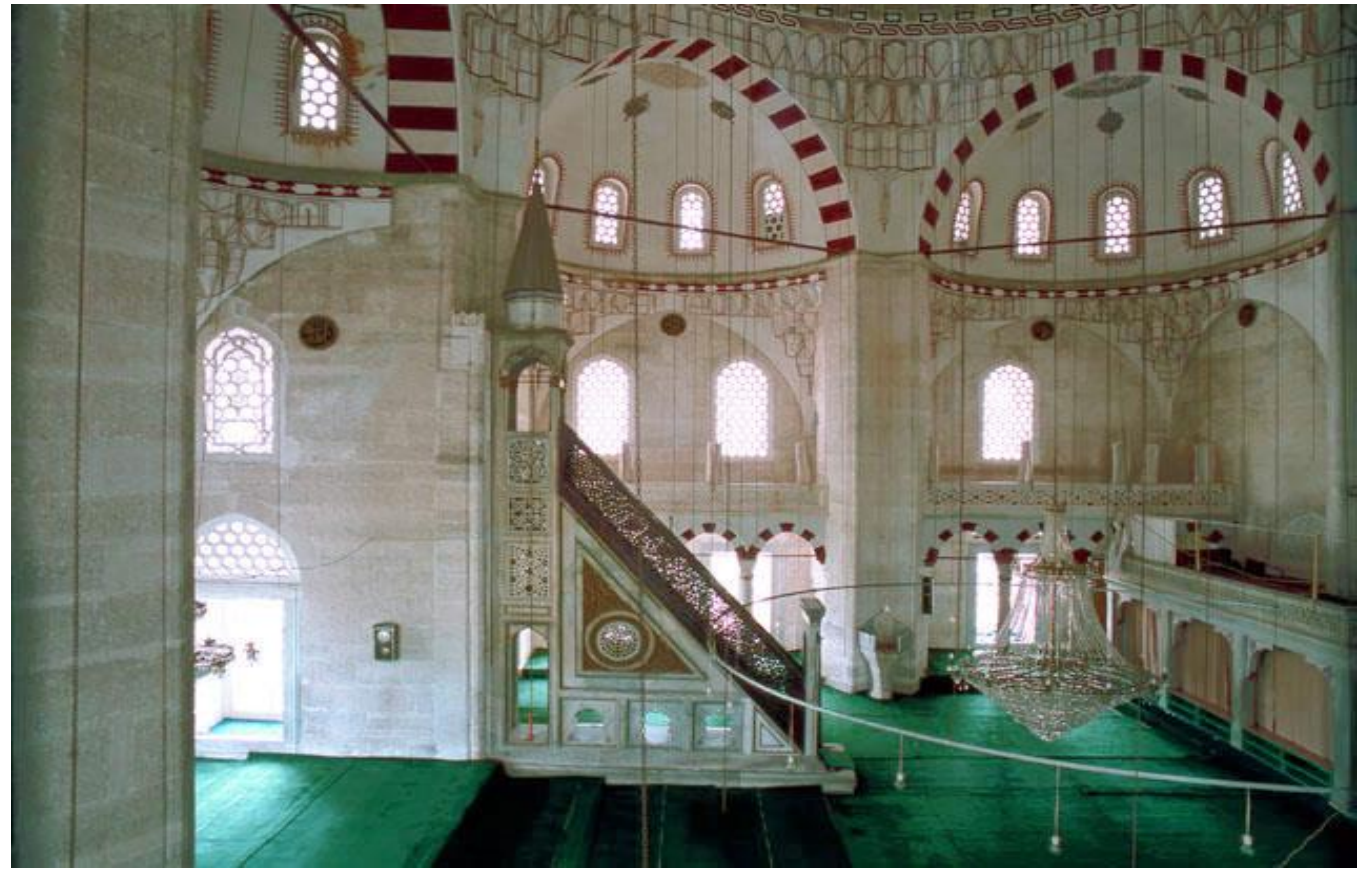

Fig 8: Babaeski Semiz Ali Pasha Mosque (Sinan Doğan).

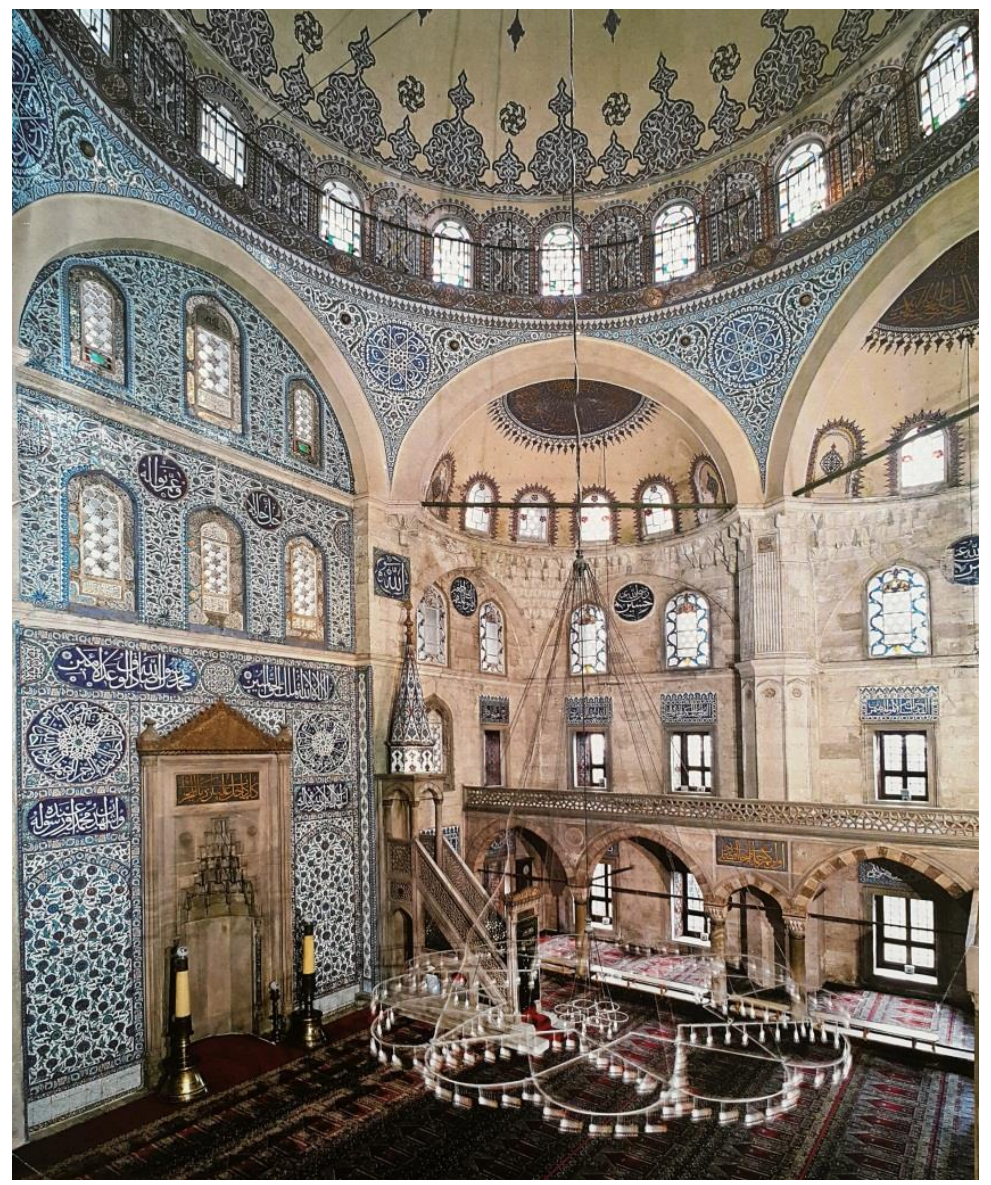

Fig 9: Kadırga Sokullu Mehmed Pasha Mosque (Kuban 2007, 327). 


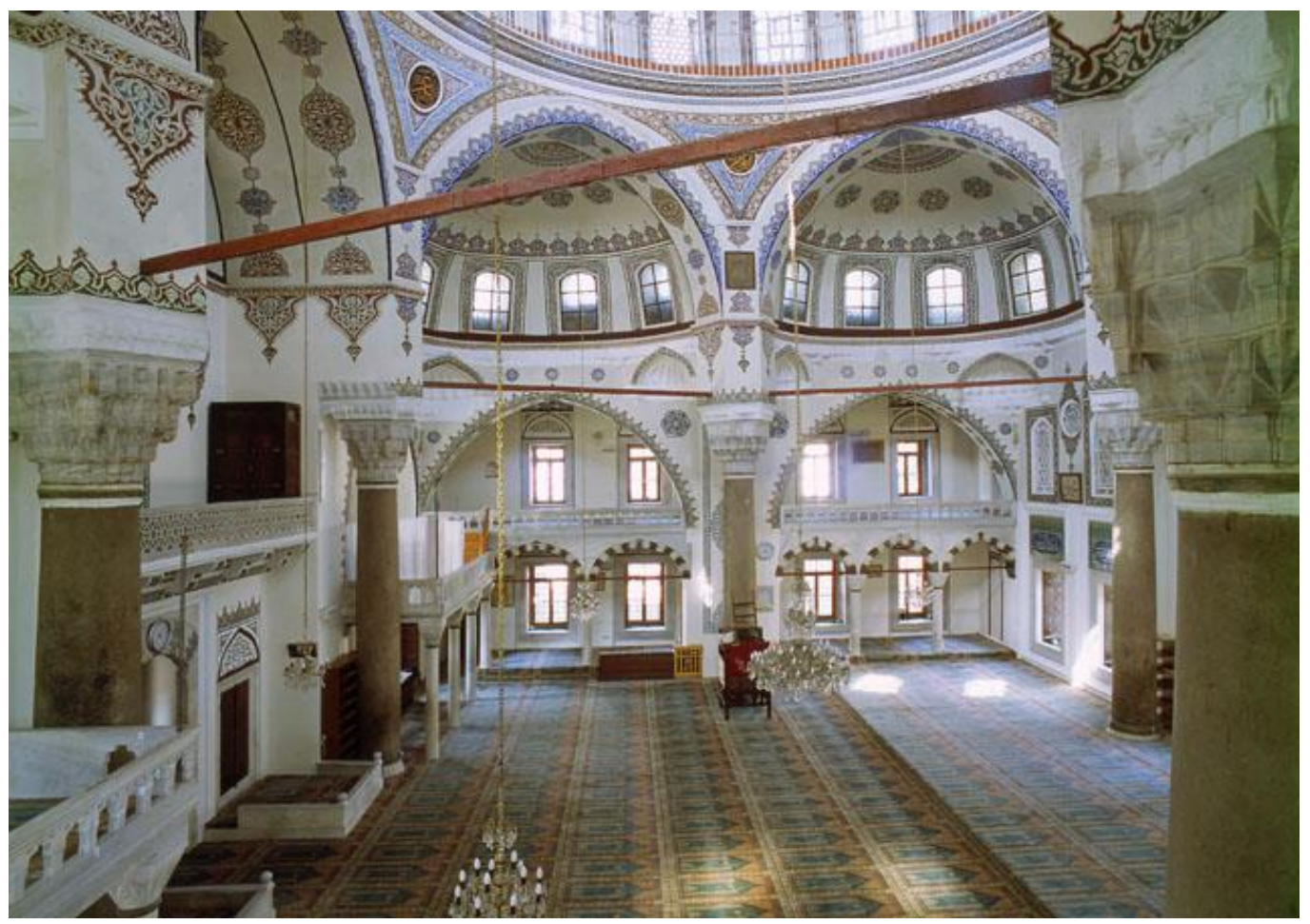

Fig 10: Topkapı Karaahmet Pasha Mosque (Mustafa Cambaz).

A fourth gallery organization that Sinan uses in the hexagonal baldachin structure is the arrangement where these areas are on one floor and appear between wall piers that are held together by windowed squinches. This type of arrangement is seen in only one structure-Fındıklı Molla Çelebi Mosque, where Sinan places raised single-story side galleries between polygonal wall piers on the east-west axis of the central hall, their facades revealing two rows of fresco (revzen) windows, flat on the lower row and with pointed arches on the upper level (Figure 11).

In the group of buildings where Sinan has preferred to use an octagonal baldachin form, the distribution in the interior of the loadbearing pillars that carry the octagonal substructure, on which the domed central covering rests, as well as the arrangement of the galleries surrounding the cental baldachin, is again characterized by different structural schemes and spatial constructs. According to Doğan Kuban, the reason Sinan chose to experiment with the octagonal baldachin system is because the octagonal baldachin is a more suitable form that can withstand the stress of the dome since the eight-pillar scheme provides a means to divide the load among more elements. This allows for an optimum solution for achieving the continuity between the substructure and the upper structure due to the reduction in the dimensions of the transitional elements between the substructure and roof covering (Kuban, 1988, pp. 581; 2007, pp. 99-100). The octagonal canopy, which transfers the load of the dome to the loadbearing system at eight points, is a better choice for bearing the stress effects of the dome and thus maintains the dome's dominance by means of a more balance structural system (Erzen, 1988, p. 78).

The Sinan implements the domed central octagonal baldachin in four ways in this typological group of buildings. The first of these can be seen in Tahtakale Rüstem Pasha Mosque, where four of the pillars stand independently inside the space on an east-west axis and four are used as wall piers in the direction of the mihrab and entrance (on the north) (Figure 5). The second way this baldachin construct is used is visible in Hadim Ibrahim Pasha and Mesih Mehmet Pasha Mosques. In these structures, the octagonal baldachin carrying the weight of the dome is supported in all directions by 
wall piers, set into the walls two by two (Figures 5,6 ). The third pillar construct in this theme is represented by Nişancı Mehmed Pasha Mosque, where this time, the octagonal plan is achieved by the eight polygonal piers connected to the building's body walls at the corners (Figure 6). The last design group in which octagonal vertical pillars are localized in different ways within the main area is seen at Edirne Selimiye and its successor Azapkapı Sokullu Mehmet Pasha Mosques. Here the great architect has planted two of the eight pillars in front of the mihrab, joining another two to the mihrab wall, leaving the remaining pillars freestanding in the man area (Figure 7). In this group of buildings, Sinan uses additional pillars outside of the baldachin to reinforce the main loadbearing pillars that form the basic structure. Used at Edirne Selimiye and Azapkapı Sokullu Mehmet Pasha Mosques, this technique is manifested by secondary loadbearing pillars on a square plan that stand beside the piers on the north side.

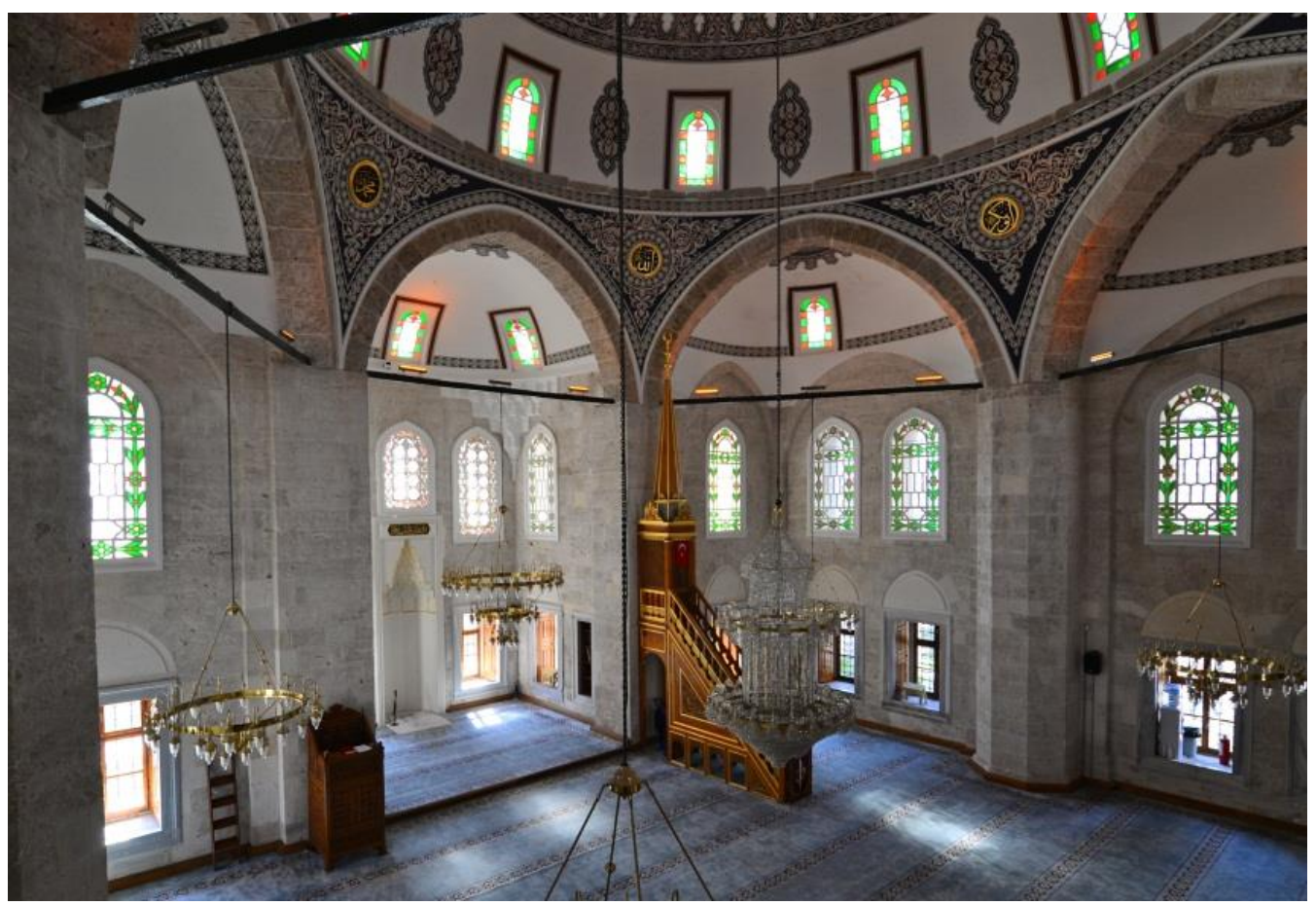

Fig 11: Fındıklı Molla Çelebi Mosque (Sinan Doğan).

The main loadbearing pillars on which the central domed octagonal baldachin rests are sometimes supported by buttress elements that project inwards or outwards. This buttress system that carries the load and stress of the dome can be felt strongly in Selimiye Mosque. The main pillars and buttresses are joined together by connecting arches in this system and were used again in Azapkapı Sokullu Mehmet Pasha Mosque, where the vertical pillars are supported by wall piers that have been placed inside the walls on all sides and project out into the main space. The piers here act as buttresses.

In Sinan's buildings that feature an octagonal baldachin system, the octagonal substructure on which the dome rests has another spatial characteristic in its construct, this being that the pillars joined to the wall on the lower floors are separated from the wall at the gallery level, increasing the structural effect. Sinan made use of this experiment at Nişancı Mehmet Pasha and Mesih Mehmet Pasha Mosques, designing the pillars with octagonal bases and embedding some of them into the walls or pier walls of the lower floors while separating the pillars from the wall and accentuating them as from the level of the galleries (Figure 14, 15) (Goodwin, 1971, pp. 45-46). Thanks to the independently standing pillars, the loadbearing system is free on the upper floor, thus adding 
structural expression to the building and accenting the structural design while at the same time providing the upper floor with a gallery that is both expansive and spacious. The pillars separated from the wall are joined to the wall with connecting arches.

Sinan tries another experiment in this group of buildings. This new experiment was manifested in Edirne Selimiye and Azapkapı Sokullu Mehmet Pasha Mosques and consists of an ambulatory stretching out in-between the galleries and the domed and covered central octagonal canopy situated in the back of the structural pillars that make up the octagonal form. This motif of the ambulatory or corridor used in Islamic architecture is a legacy of Late Roman-Early Byzantine times. There is, for example, an aisle (ambulatory) to be seen between two interwoven octagonal forms in Kubbet-üs Süleybiye, a structure dated to 862 A.D. in the time of the Abbasids and mentioned in history as the first Islamic tomb. Doğan Kuban says that the inspiration behind Sinan's concept of an octagonal form inside a square can be traced to Olcayto Türbesi, which he saw on a campaign to Baghdad (Kuban, 1988, p. 581; Kuban, 2007, pp. 67-68). Gülru Necipoğlu comments that Sinan's Edirne Selimiye ambulatory resembles Kubbet-üs Sahra (Necipoğlu, 1996, p. 178; Necipoğlu, 2013, pp. 45-46). There is a good chance that Sinan's notion of the domed central space with passages, a two-story gallery with an octagonal canopy goes back to the Sergios and Bakhos Church (Küçük Ayasofya Mosque) built by Justinianos I in 527-536.

Sinan Agha's concept of a single total space underneath a dome is quite creative and nonrepetitive in the organization of the side galleries in buildings constructed on the basis of an octagonally supported system. Sinan used impressive spatial compositions in the secondary units of his buildings. He uses three types of side gallery in buildings of this type. The first and earliest of these buildings where he uses an octagonal support system is Hadim Ibrahim Pasha Mosque. Here, Sinan has designed the side galleries on a single story and on a higher level than the central space, in the form of shallow spaces (maksure) that are situated on wall piers that project into the main space on the east, west and north sides (Figure 12). The galleries have two rows of windows and the middle gallery is wide and split into three compartments, providing a sense of spaciousness. Another example of the side gallery design is in Tahtakale Rüstem Paşa Mosque, where this time, the side galleries on the east-west are in back of the freestanding main pillars and the buttress supporting the main pillars have been settled in-between the wall piers in the form of four-compartment, twostoried, low and narrow side galleries (Figure 13). Both stories have domed side areas that look out onto the space with cavetto vaulting on the upper floor on the inside; these areas are in full integration with the domed central space.

Another type of side gallery organization that Sinan created can be seen in Nişancı Mehmed Pasha Mosque. Each pillar forming the octagonal structure is tied to the walls of the body of the building with polygonal piers and Sinan has placed the side galleries between the pillars on the east, west and north sides (Figure 14, 15). He has designed the wider and higher middle side gallery on the east-west side as a two-compartment, two-story area. This middle side gallery is covered by a semidome and the space on both floors looks down into the main area below. The second unit in the north corner is again two-storied but this time has been designed in the form of a room that connects to the tabhane rooms at the north corner of the lower floor and is in contact with the harim by means of only one window. On the upper stories, between the wall piers that have been separated from the wall to rise up independently are spaces opening out into the harim prayer hall) that are accessed through an arch that is at a lower level than the middle gallery. The galleries on the north side are again arranged in the same way. They appear to be looking down upon the interior space from in-between the free-standing piers that have been pulled away from the wall. 


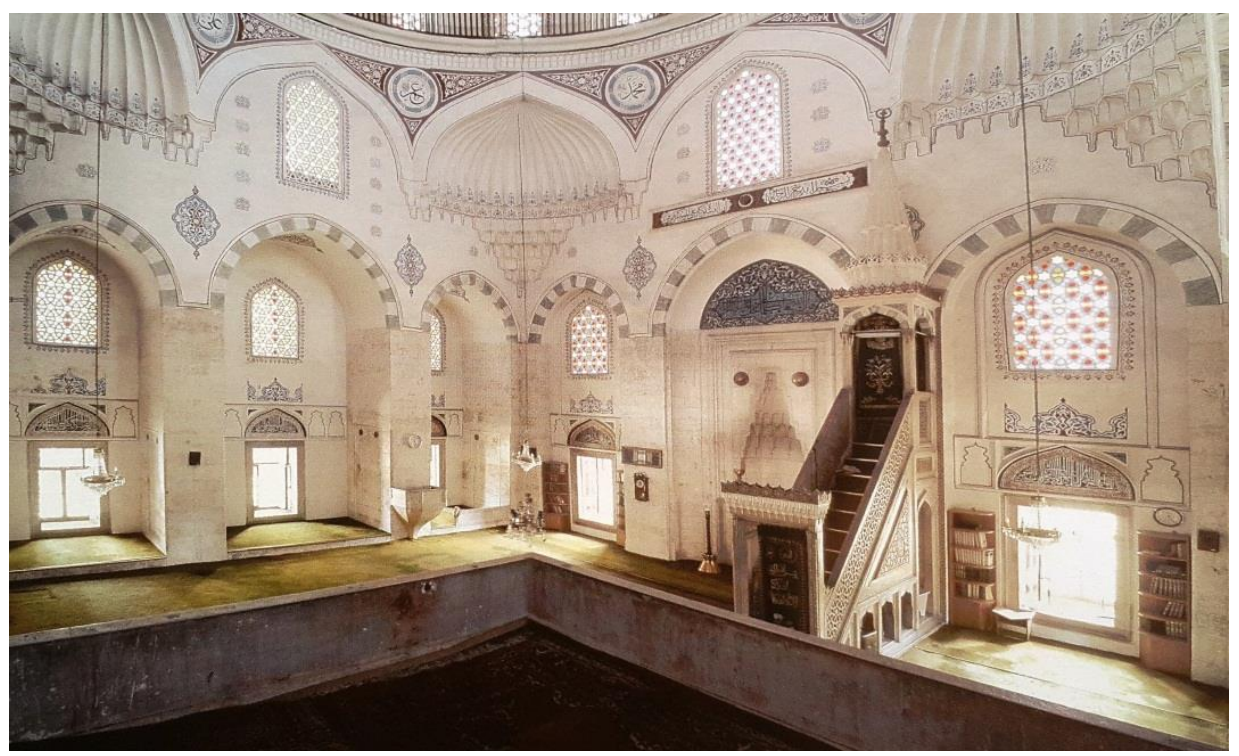

Fig 12: Hadım İbrahim Pasha Mosque (Günay 2002, 34).

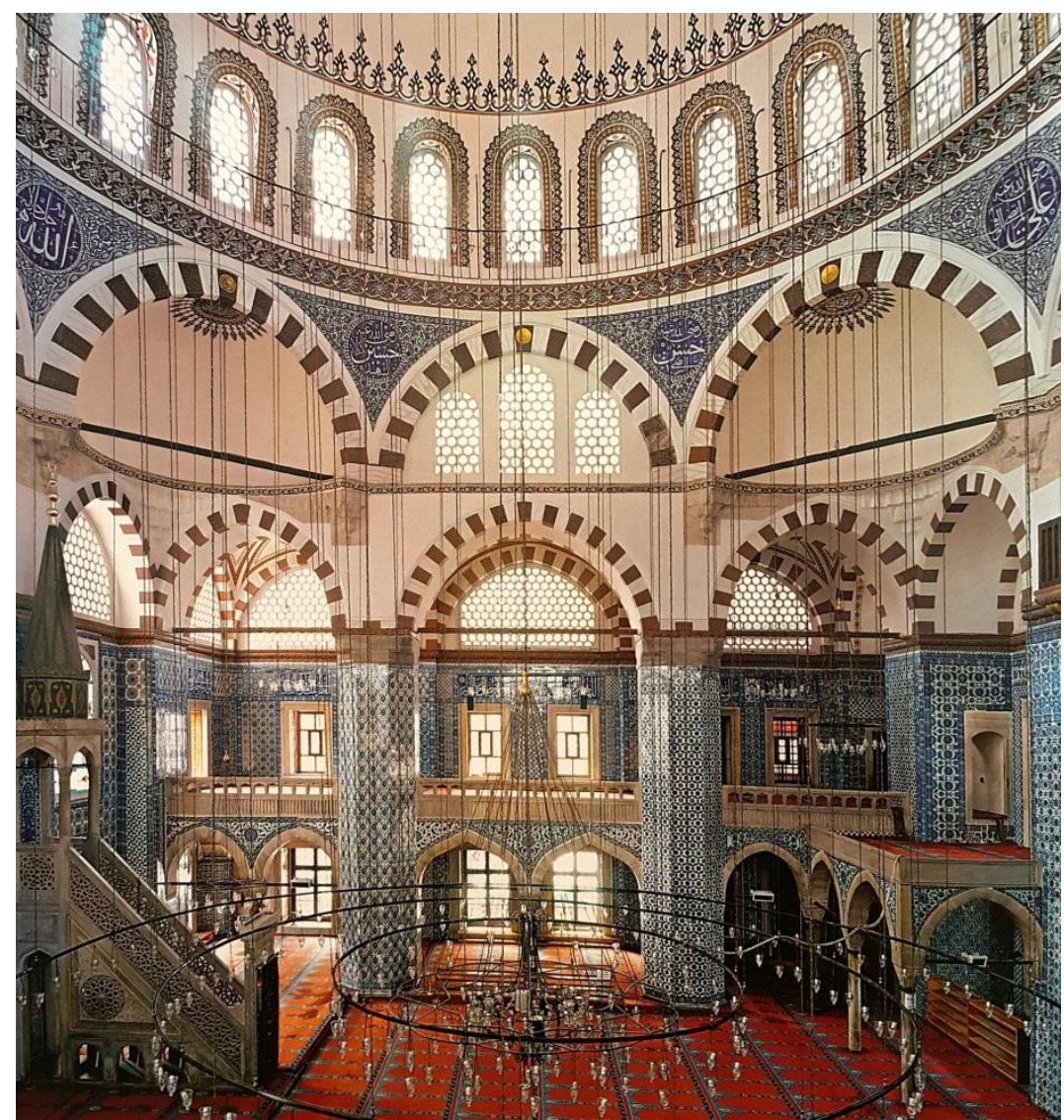

Fig 13; Tahtakale Rüstem Pasha Mosque (Kuban 2007, 123).

Sinan uses the side gallery organization similar to the one he used in Nişancı Mehmed Pasha Mosque at Mesih Mehmet Pasha Mosque, dated to 1586. Here, the side galleries on the west and north sides are two-storied and have been settled in between wall piers forming the central octagonal base that are joined to the wall on the ground floor but separated from the wall on the upper story, (Figure 16). On the east-west side, two of the three-compartment side galleries (mahfil) 
look toward the central space on the lower floor with windows while the mahfil on the north opens out into the harim with a door. This door is a connecting element between the inside and outside of the structure. In contrast to this design, where the side galleries are separated from the main space on the lower floor, giving them the function of an external rewaq that does not project outwards from the main mass of the building, on the upper floor, the piers that have been pulled away from the body walls open out into the harim with three pointed arches on each side. In this arrangement, the construct of these side areas are different on the lower and upper story and thus do not fully integrate on the lower story with the domed central space.

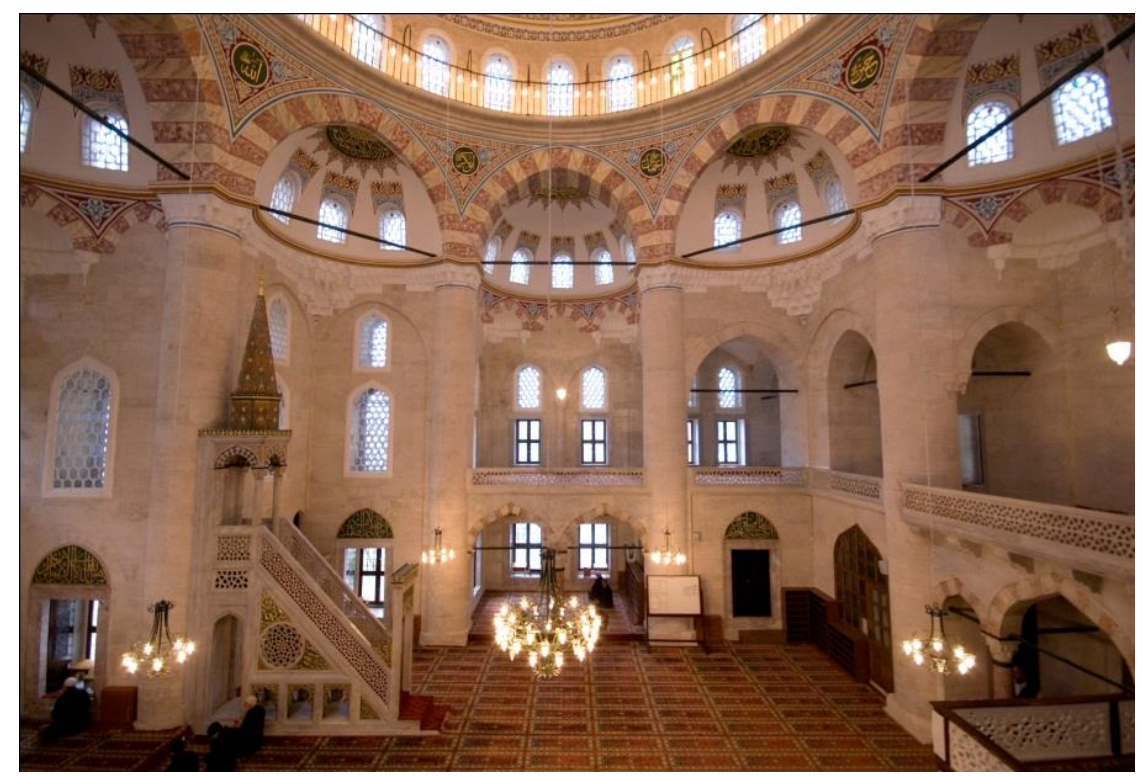

Fig 14; Fatih Nişancı Mehmed Pasha Mosque. Side galleries and piers separated from the wall on the mahfil floor on the north (Sinan Doğan).

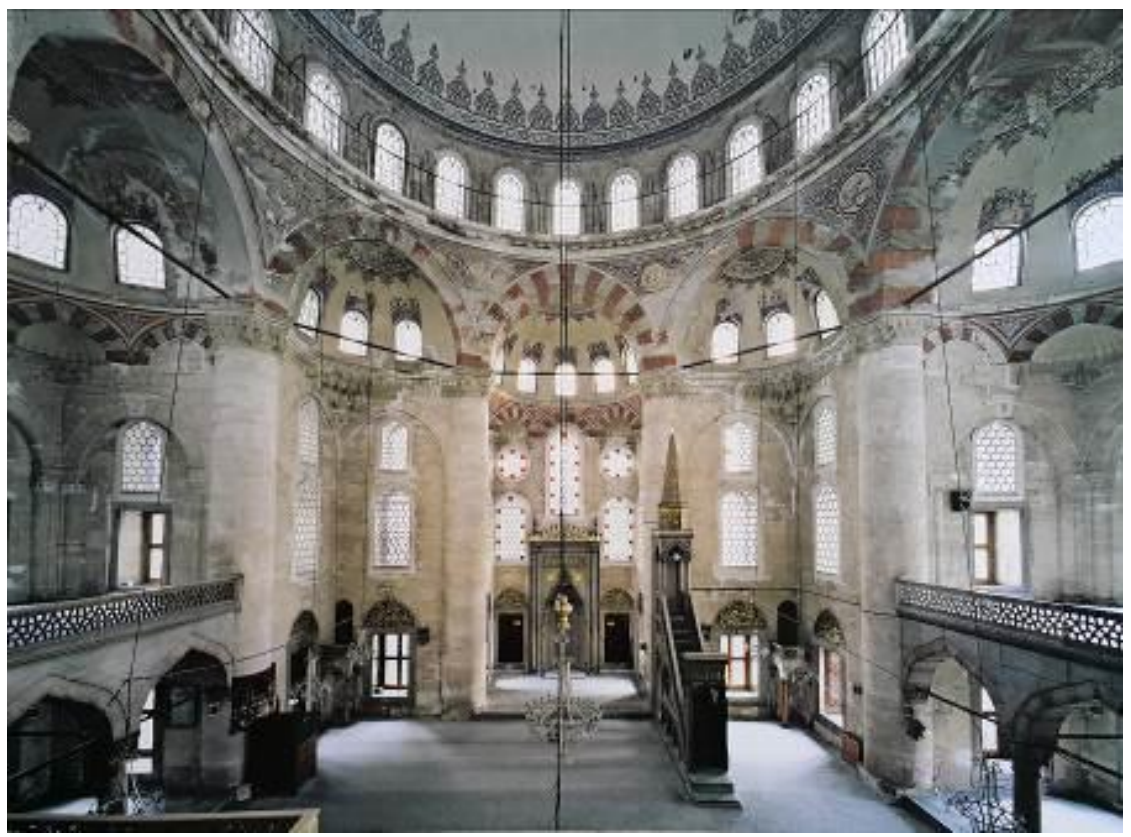

Fig 15; Fatih Nişancı Mehmed Pasha Mosque. Interior (harim) (Kuban, 2007, 382). 
By preventing the side galleries from spreading out into the central space on the ground floor, Sinan has made use of asymmetry, where the upper floors look out onto the interior and the interior construct displays a much different attitude. Another structure where Sinan uses this plan is Edirne Selimiye Mosque. In this building, the side galleries on the east-west sides have been placed between the buttress columns and as in Mesih Mehmet Pasha Mosque, the only one of the threecompartment, two-storied galleries on the north has a door opening out into the harim on the lower floor (Figure 17, 18). The other two spaces on this side strike a dialogue with the main area covered with an octagonal canopy dome only by means of its windows. The galleries look onto the main area over a bannister with Bursa arches while the upper floors look down from under three pointed arches. Both floors of the side galleries situated in-between the square-based secondary pillars built as an addition to the polygonal pillars in the north look over the main space.

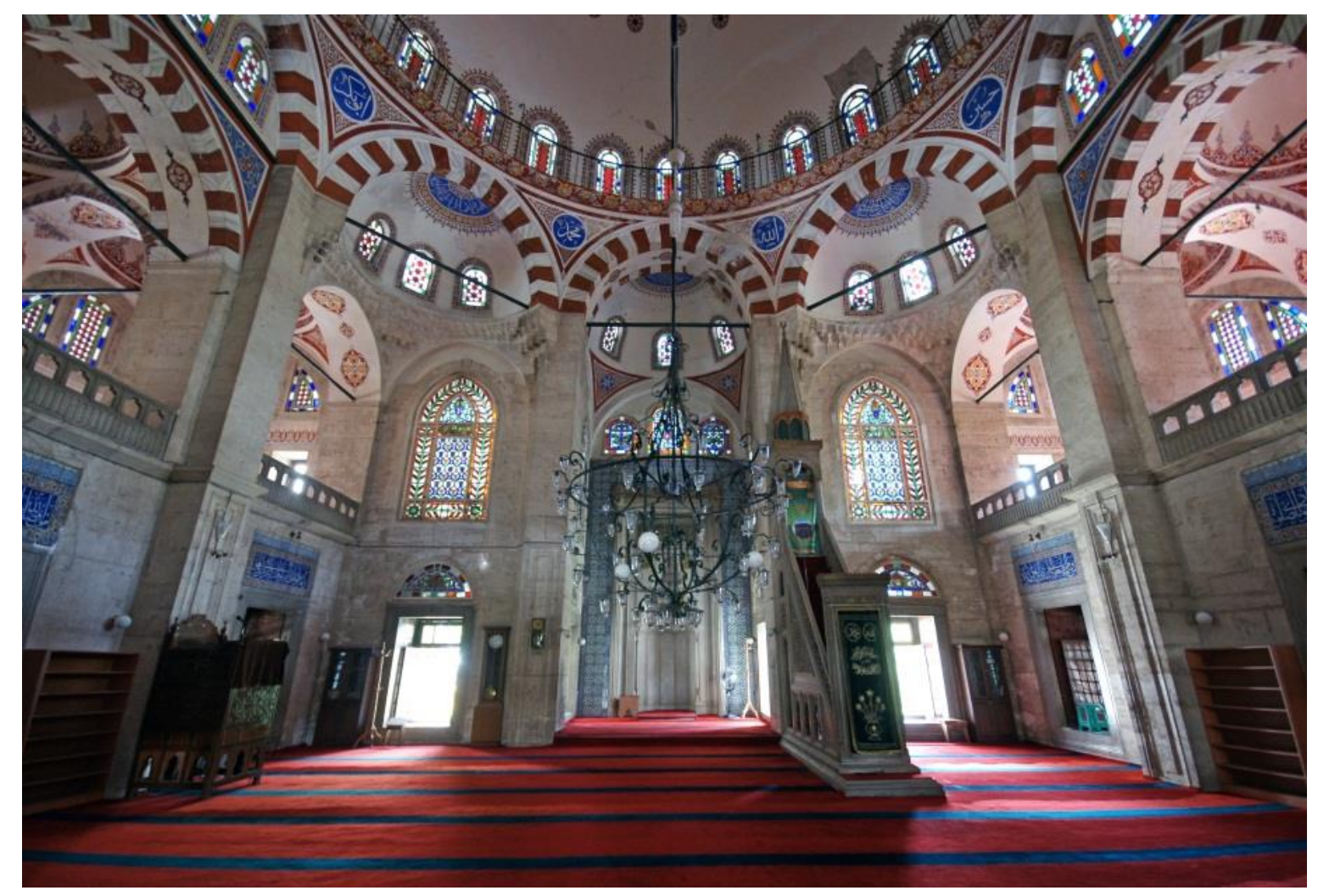

Fig 16; Mesih Mehmed Pasha Mosque. Upper stories of the side galleries opening out into the interior space (Sinan Doğan), 


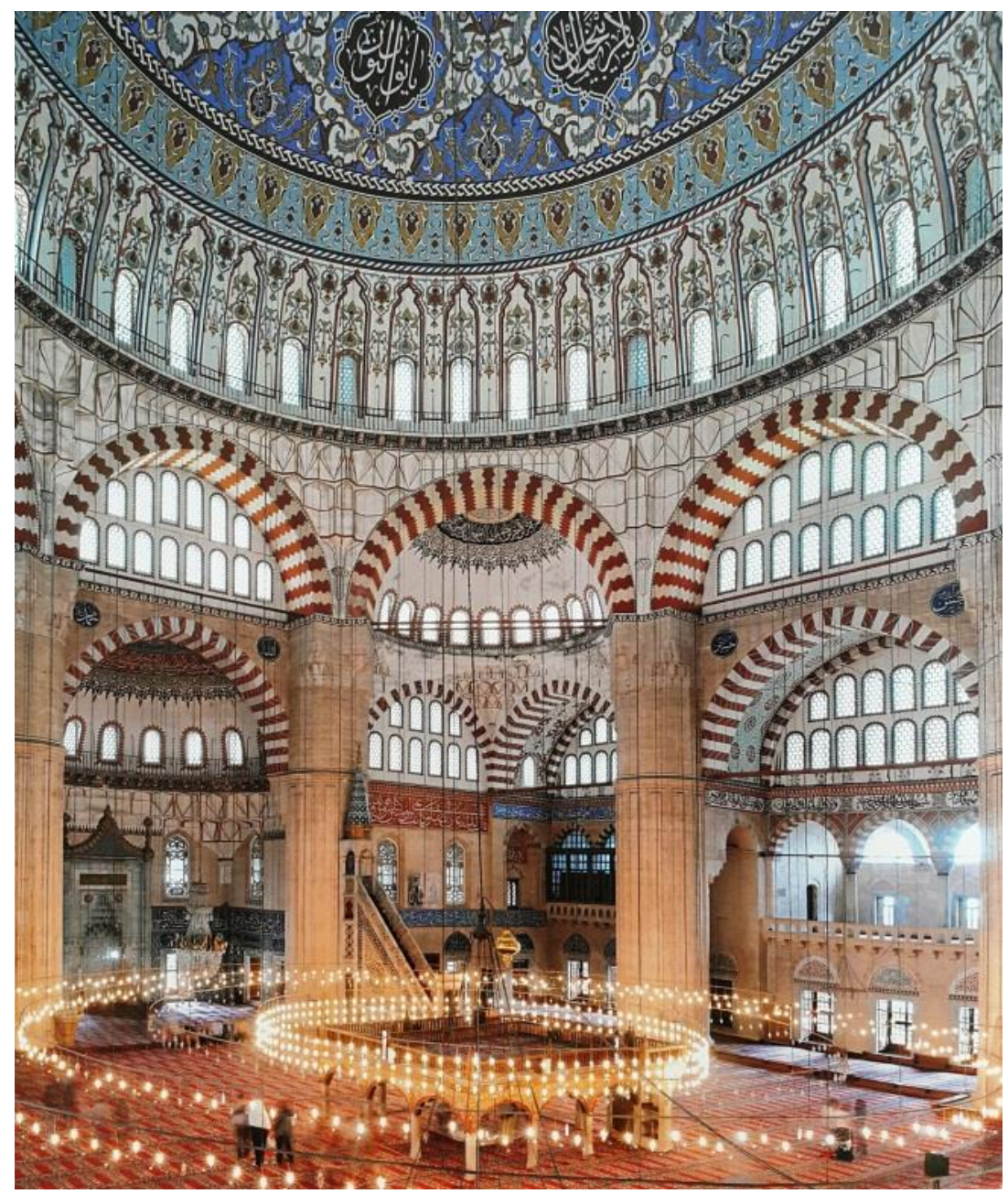

Fig 17; Edirne Selimiye Mosque interior (Kuban 2007, 432).

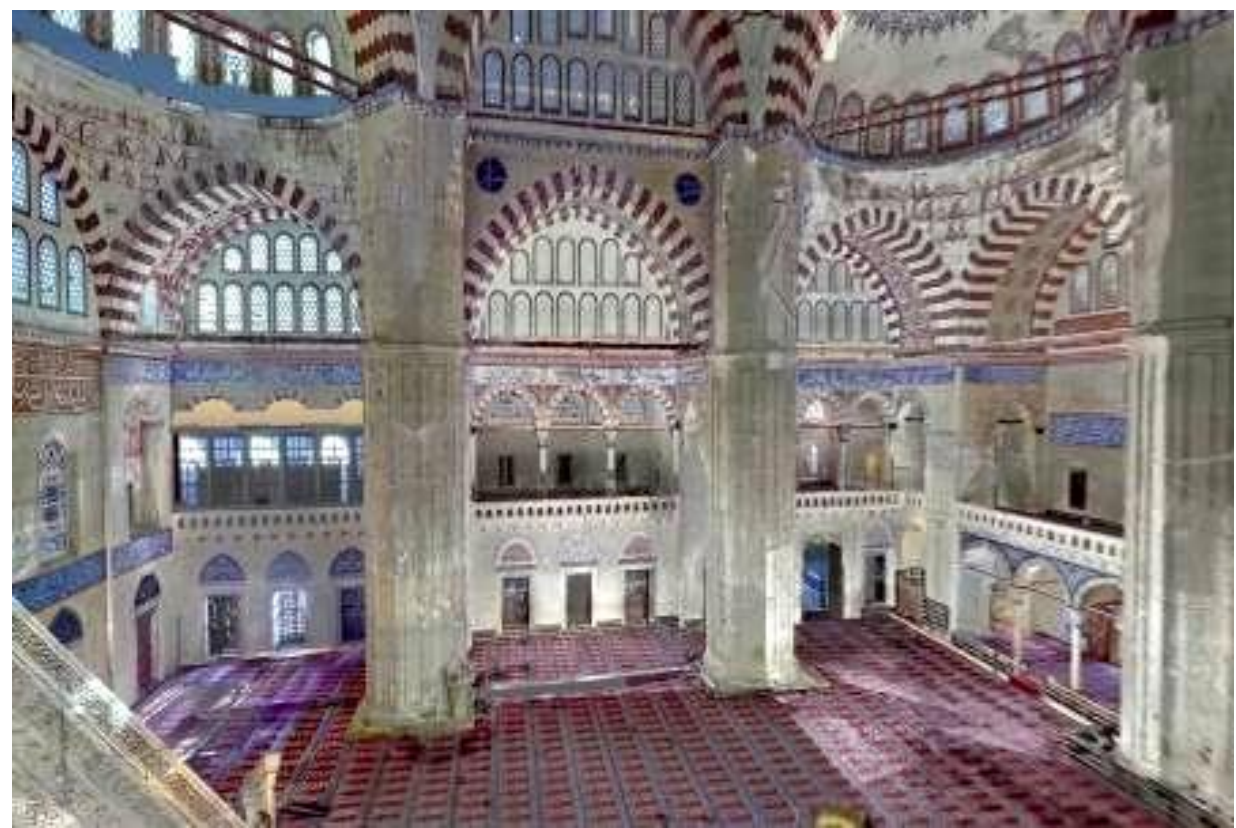

Fig 18; Edirne Selimiye Mosque. Side Galleries (Mustafa Cambaz). 
Another spatial design for peripheral areas built in the octagonal baldachin concept by Sinan, who unmistakably left an indelible imprint on Turkish architecture, can be seen in Azapkapı Sokullu Mehmet Pasha Mosque. Regarded as a continuation of the concept laid out at Edirne Mosque, this building has a similar construct and structural system. As in Selimiye, Sinan has placed the side galleries in-between the wall piers projecting out into the main area as supporting elements of the freestanding pillars forming the baldachin. The three-sectioned galleries propped by columns on the lower floor, at a higher level than the main area and with the section in the middle wider than the others, are integrated with the harim on both floors here and open out into the main area (Figure 19).

In this group of buildings, Sinan assigns a different character to the side galleries on each wing, creating a dynamic and energetic effect to the composition. Although the side galleries are situated inside the building mass, they are nestled into another gallery system which is above the galleries on the first-floor level and looks out into the interior on the second-floor level. This arrangement can be interpreted as the most outstanding indication of the genius of Sinan in creating structural and spatial organization. This type of organization is in fact a reflection of Sinan's perception of rhythm and a technique for which he showed a preference in order to break the monotony (Kuban, 1958, pp. 12-13). These low-ceilinged galleries inside the mosque also accentuate the impact of the domed central space.

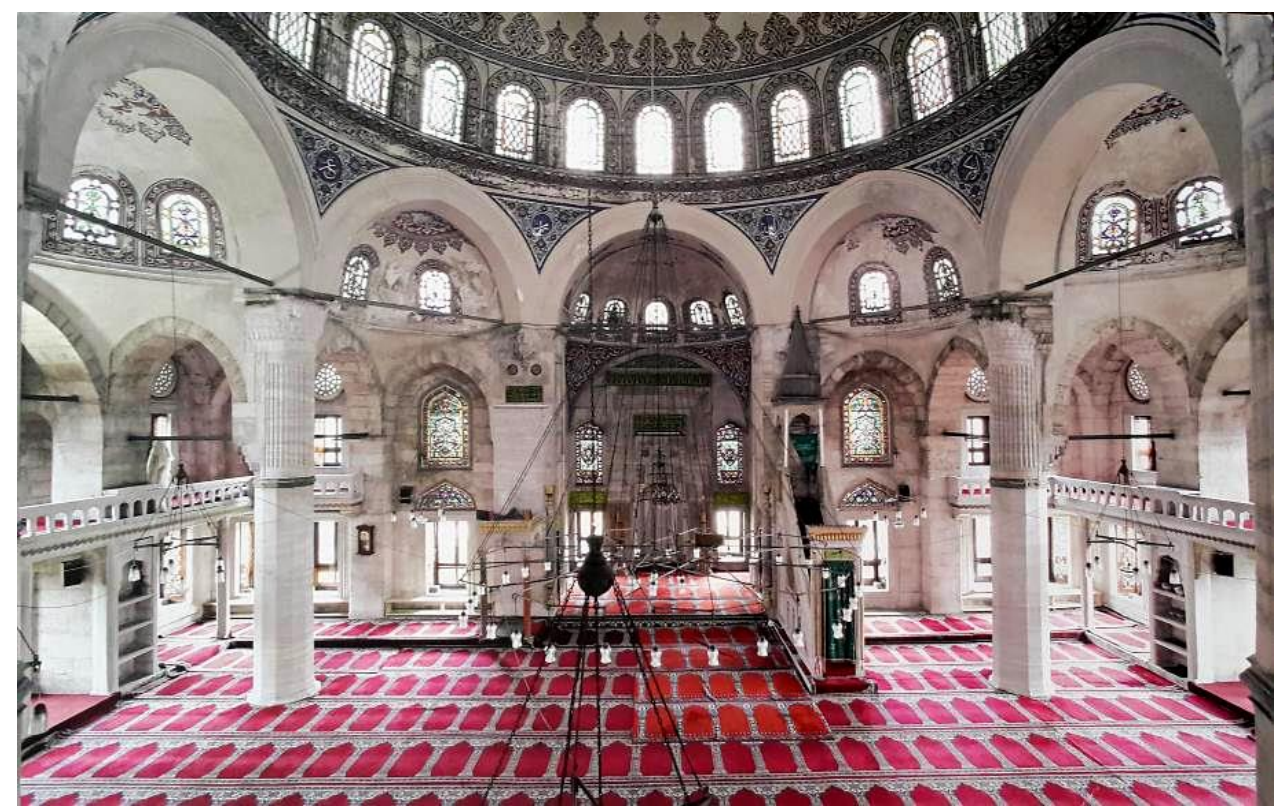

Fig 19; Azapkapı Sokullu Mehmet Pasha Mosque, interior (Kuban 2007, p. 328).

The facades of this group of mosques, in which a system of six or eight elements supporting the domed main hall was an essential part of Sinan Agha's design, are also worthy of note. As in all of the great architect's works, light is a major component of design in this typology of buildings. Sinan regarded facades as an important motif of mass design and therefore designed arches, exedra, semidomes and squinches and other elements of roof coverings or other levels of formative components of the building mass with windows to allow light to flow into the interior. Light is meant to filter down delicately through these windows into the main hall. The windows on the dome frame are an important source of light in Sinan's structures. Arches under which rows of windows are positioned take on new expression on the exterior of buildings in Sinan's time. By taking away their loadbearing role, Sinan redefines the outer walls of masonry with their two or three tiers of windows, turning them into infilled walls and making the windowed wall a significant element of design in his works. 
This type of infilled facade wall system appears to take on the identity of illuminated curtains as it took its place inside the articulation of the building's loadbearing mechanisms. This concept has in fact reached extraordinary expression given the science of its times (Kuban, 1988, p. 583). From the exterior, the windows are aligned in different rhythms, creating a wealth of variety of styles and a unique architectural texture (Kuban, 2007, p. 327). The loadbearing elements project into the exterior, providing the structure with a sense of mass motion. The structural elements of buttresses and the suspended and discharging arches reaching over these structures dominate the formation of the mass.

\section{Conclusion}

The master architect Sinan explored the means of creating a central space in all of his buildings and in fact made this quest his main goal. Centrality was a fundamental vision in his architectural construct and his principal focus was on using the dome as a means of providing visual and spatial integrity to the organic building structure. For Sinan, the dome is an architectural element that has the multipurpose of creating both a central and plenary spatial presence as well as a symbolic effect. His domes, appearing in small, medium-size as well as in monumental dimensions, are parts of an ideal central plan.

Sinan implemented the concept of a centralized composition that focuses on the dome with different structural systems that produce a variety of spatial visions. The masterful use of structural elements plays a major role in the construct of both the interior space and the structural mass. In the design of the domed central space created with a hexagonal or octagonal baldachin system, the relationship between the interior space-structure and the roof covering-side galleries is an exemplary meeting of aesthetic design. The layout of the main structure, in which a central dome rests on a hexagonal or octagonal pillar base, is different in each building. At the same time, the centrality of the plan is accentuated by the hexagonal and octagonal baldachin system, lending a new perspective to the concept of the centralized layout. In the structures that feature a hexagonal or octagonal base, elements rise from the ground to the main dome in degrees, providing a sense of motion in the interior as the exterior. With the addition of frontal design, the centralized plan and the hexagonal and octagonal baldachin structural system resting in a square plan stand out as a new style that carries the unique signature of Sinan.

\section{References}

Ahunbay, Z. (1988). Mimar Sinan'ın Şehirci Yönü. In I.Ateş, S. Bayram, M. Narince (Eds.), VI. Vakıf Haftası. Türk Vakıf Medeniyeti Çerçevesinde Mimar Sinan ve Dönemi Sempozyumu, İstanbul: Vakıflar Genel Müdürlüğü Yayınları, 134-152.

Aslanapa, O. (1986). Osmanlı Devri Mimarisi, Istanbul: Inkılap Kitabevi.

Batur, S. (1969). Osmanlı Camilerinde Sekizgen Ayak Sisteminin Gelişmesi Üzerine, Anadolu Sanatı Araştırmaları I (1969), 139-168.

Benian, E. (2011). Mimar Sinan ve Osmanlı Cami Mimarisinin Gelişimindeki Rolü, Bilim ve Teknik Ocak 2011, 4047.

Binan, D. (2016). Molla Çelebi (Fındıklı) Camii. In T. Taşdemir (Eds.), Mimar Sinan'ın İstanbul'u, İstanbul: Türkiye Turing ve Otomobil Kurumu, 242-246.

Binan, D. (2016). Sokullu Mehmet Paşa Camii. In T. Taşdemir (Eds.), Mimar Sinan'ın Isstanbul'u, İstanbul: Türkiye Turing ve Otomobil Kurumu, 324-330. 
Cezar, M. (1977). Anadolu Öncesi Türklerde Şehir ve Mimarlık, Istanbul: Türkiye İş Bankası Kültür Yayınları.

Erzen, J. (1988). Sinan as Anti-Classicist, Muqarnas V, 78.

Erzincan, T. (2004). Mesih Paşa Külliyesi, TDV İslam Ansiklopedisi 29, 310-312.

Eyice, S. (1992). Ivaz Efendi Cami, TDV İslam Ansiklopedisi 4, 490-492.

Eyice, S. (1994). Sokullu Mehmed Paşa Camii, Dünden Bugüne İstanbul Ansiklopedisi 7, 30-31.

Eyice, S. (2000). Ibrahim Paşa Külliyesi, TDV İslam Ansiklopedisi 21, 341-343.

Goodwin, G. (1971). A History of Ottoman Architecture, London: Thames\&Hudson.

Günay, R. (2002). Mimar Sinan, Istanbul: Yem Yayınları.

Günay, R. (2006). The Space-Structure Relation in Sinan's Works. In R. Aguilar, D.Torrealva, S. Moreira, M. A. Pando, L. F. Ramos (Eds.), Structural Analysis of Historial Constructions, RILEM Book Series: Springer, 211217.

Kuban, D. (1958). Osmanlı Dini Mimarisinde iç Mekan Teşekkülü. Rönesansla Bir Mukayese, Istanbul: İstanbul Teknik Üniversitesi, Mimarlık Fakültesi.

Kuban, D. (1988). Sinan'ın Dünya Mimarisindeki Yeri. In S. Bayram (Eds.), Mimar Başı Koca Sinan. Yaşadığı Çağ ve Eserleri, Istanbul: Vakıflar Genel Müdürlüğü, 581-624.

Kuban, D. (1994). Nişancı Mehmed Paşa Camii, Dünden Bugüne Istanbul Ansiklopedisi 6, 85-87.

Kuban, D. (1994a). Sokollu Mehmed Paşa Külliyesi, Dünden Bugüne Istanbul Ansiklopedisi 7, 32-34.

Kuban, D. (1996). İstanbul Bir Kent Tarihi, Istanbul: Tarih Vakfı Yurt Yayınları.

Kuban, D. (1997). The Style of Sinan's Domed Structure, Muqarnas 4, Issue 1, 72-97.

Kuban, D. (2007). Osmanlı Mimarisi, Istanbul: Yem Yayınları.

Kuban, D. (2011). Sinan'ın Sanatı ve Selimiye, Istanbul: İş Bankası Kültür Yayınları.

Kuran, A. (1976-77). Mimar Sinan'ın Eserleri ve Camileri Konusunda Kısa Bir Değerlendirme, Boğaziçi Üniversitesi Dergisi Hümaniter Bilimler 4-5 (1976-77), 83-90.

Kuran, A. (1986). Mimar Sinan, Istanbul: Hürriyet Vakfı Yayınları.

Mülayim, S., Çobaoğlu, A. V. (2009). Selimiye Camii ve Külliyesi, TDV İslam Ansiklopedisi 36, 430-434.

Necipoğlu-Kafadar, G. (1986). Plans and Models in 15th-and 16th- Century Ottoman Architectural Practice, JSAH Vol. 45, No. 3 (Sep. 1986), 224-243.

Necipoğlu, G. (1996). The Emulation of the Past in Sinan's Imperial Mosques. In A. A. Yaşa, Uluslararası Mimar Sinan Sempozyumu Bildirileri, Ankara: Türk Tarih Kurumu, 177-189.

Necipoğlu, G. (2005). The Age of Sinan: Architectural Culture in the Ottoman Empire, Princeton and Oxford: Princeton University Press.

Necipoğlu, G. (2013). Sinan Çağı: Osmanlı Imparatorluğu'nda Mimari Kültür. Istanbul: İstanbul Bilgi Üniversitesi Yayınları.

Okçuoğlu, T. (1994). Mesih Mehmed Paşa Camii, Türbesi ve Çeşmesi, Dünden Bugüne İstanbul Ansiklopedisi 5, 406-407.

Sönmezer, Ş. (2003). Istanbul'daki Sinan Camilerinde Mekan ile Serbest Düşey Taşıyıcılar Arasındaki Boyut ilişkisi, Istanbul: İstanbul Teknik Üniversitesi Fen Bilimleri Enstitüsü.

Tanman, B. (1994). Atik Valide Külliyesi, Dünden Bugüne İstanbul Ansiklopedisi 1, 407-412.

Tanyeli, U. (1990). Sinan Mimarlığında Dış Mekân Biçimlendirilmesi, Mimarlık Dergisi 240, 68-71.

Turani, A. (1997). Dünya Sanat Tarihi, Istanbul: Remzi Kitabevi.

Yılmaz, C. (2015). Mesih Mehmet Paşa Camii. In B. Katkak (Eds.), Büyük Usta Mimar Sinan, Istanbul: Çekül Vakfı, 66-69. 